\title{
APURDUTI
}

Euskal ikerketen aldizkaria | Revue d'études basques |

Revista de estudios vascos | Basque studies review

$17 \mid 2013$

Numéro XVII

\section{Oikiako Dotrinak : F. Antonio Agirre Gabiria (Marin 1728 - Oikia 1805)}

\section{Koro Segurola}

\section{OpenEdition}

\section{Journals}

Édition électronique

URL : https://journals.openedition.org/lapurdum/2466

DOI : 10.4000/lapurdum.2466

ISSN : 1965-0655

Éditeur

IKER

Édition imprimée

Date de publication : 1 octobre 2013

Pagination : 223-253

ISBN : 978-2-86781-409-9

ISSN : $1273-3830$

Référence électronique

Koro Segurola, «Oikiako Dotrinak : F. Antonio Agirre Gabiria (Marin 1728 - Oikia 1805)», Lapurdum [Linean], 17 | 2013, Sarean emana----an 15 novembre 2015, kontsultatu 22 juillet 2021. URL: http:// journals.openedition.org/lapurdum/2466 ; DOI: https://doi.org/10.4000/lapurdum.2466 


\section{Oikiako Dotrinak. \\ F. Antonio Agirre Gabiria (Marin 1728 - Oikia 1805)}

Koro SEGUROLA

\section{Sarrera}

Izenburua ez da oharkabean itzuritako hutsa, aspaldian Oikiako «aurrenzat» idatzitako ikasbidearen ale ezagun bakarraz gainera, beste bat agertu berri baita gure artean ${ }^{1}$. «Obligacio pisuari erantzuteco quezcac» eraginik eta Oikian bere kontura zituen «Animen oneraco», bertako bikarioak apailatu beste ale argitaragabe baten berri ematera gatozkizue. Dotrina «berri» hau Lazkaoko beneditarren monasterioko Euskal Liburutegiko liburu eta eskuizkribu artean aurkitu dugu².

Esku artean dugun eskuizkribu «berriak» Christau-ac Ezaguera arrazoizcora elduezquero Sinistu Jaquin, ta Eguin beardituan gaucen jaquin videa darama izenburutzat. Aurkezpenean, ez dugu euskal testuetan hain ezaguna zaigun Asteteren izena irakurtzen; bai, ordea, «Oikiako Dotrina (1759)»ra garamatzan beste hau: D.n Francisco Antonio Aguirre, Oquiaco Vicarioac atera-a ta compondua. Ikasbide hau noiz idatzi zuen, ordea, ez dakigu, ez baitu urtea adierazten.

Ezaugarri arrunta da eskuizkribuekin lan egitea egokitu zaigunoi, zenbatetan ez dugun ez egilearen ezta testua idatzi zen urtearen berririk ere bertan edo zuzenean aurkitu, eskutitz eta antzeko idatzi motak alboratuta. Eskuizkribua diogunean, kodikologiak jasotzen duen ikuspegitik ulertuta, eskuz idatzia den eta halako luzera bateko testua daraman objektuaz ari gara (Ruiz García 1988: 383), eta ez testu genetikak eta kritika genetikoak aztertzen duten «eskuizkribu moderno»az, hau da, idazlana prestatzeko autoreak aurretik darabilen langai

1.- Idazlan hau duela zazpi bat urte idatzi nuen. Ezusteko baten ondorioz, ordea, ezin izan dugu orain arte argitaratu.

2.- Bertako liburuzaina den Aita Juan Joxe Agirre beneditarrari zor diogu, eta bihoazkio hemendik ere gure eskerrik beroenak. 
multzoaz (Lluch, J. in Arcocha-Scarcia, et al. 2010: 19-25)3.

Hori kontuan izanik, mota honetako eskuizkribu baten edizioa prestatzera doanak lehenik bere egoera fisikoari aurre egin behar dio, honek baldintzatuko duelako bere lana. Zenbaitetan horretan datza eskuizkribuaren lehen testu-arazoa, materiala garbiki, baina zehaztetik letorke eskuizkribura modu eraginkor batez hurbiltzeko aukera eta testu-azterketaren antolabidea. Ikuspuntu honetatik hurbildu nahi dugu Oikiako dotrina «berri» honetara, eta eskuizkribuak eskaini (ez) dizkigun eta aurrean azalarazi ditugun datuak ikustatu. Hortaz, dotrina ezagutzera emateaz gain, gure lanaren asmo nagusia da egilea eta garaia ondo finkatuta uztea, ondoko azterketetarako. Helburuen kariaz ez dugu orain testu osoa azalduko, lehen hurbilketa honetan D.n Francisco Antonio Aguirre dotrinaren egile den egiaztatu eta noiz idatzi zuen ezagutu nahi baitugu.

Horretarako, kodikologiak eskaintzen duen metodoa ezartzea lagungarri bezain baliozkoa izango dugu, aurreratu bezala. Eskuizkribuaren ezaugarriak aintzat hartu, bada, eta zehazki paperaren ur markak aztertuko ditugu zein garaitakoa den jakin ahal izateko. Agirre dotrinaren egile den egiaztatzeko, berriz, bere bizitzaren inguruko datuak eskuratu eta testuan ematen direnekin erkatuko ditugu. Bi azterketatik erdietsitako argibideak ere alderatuko ditugu, guztiak berresteko.

Dotrina «berri» hau eskuratzeak eta ondotik egindako azterketa horien emaitzek «Oikiako Dotrina (1759)» izenez ezagutzen duguna berrikustera eraman gaituzte eta, horrenbestez, bi dotrina hauek erkatzera. Hori dela eta, dotrina horretan, «Oikiako Dotrina (1759)» ezagunean, ezustekoren bat izan dugu idatzi zen urtearen aldetik. Ezustea paperaren azterketaren ondotik iritsi zaigu eta horren garrantzia agerian utzi nahi genuke azterlan honetan; izan ere, metodologia honek aurkezten dugun dotrina «berria»ren garaia jakiteko aukera eskaini digu eta denok ezagutzen dugun Oikiako beste dotrinaren egilea eta data egiaztatzera bultzatu.

Lehenik, oraintsu agertu den eta gure eskuetara heldu den dotrina aurkeztuko dugu (§ 1). Ondoren, Jesulagun, Gipuzkoako Protokolo eta Elizbarrutietako Agiritegietako dokumentuetan oinarrituz F. A. Agirre ezagutuko dugu (§ 1.1), eta Oikiako Dotrina «berria»ren egile den egiaztatuko ( $(1.2)$. Ezkutuan edo esan gabe utzi zuen dotrinaren urtea aztertuko dugu jarraian ( $\S 1.3$ ). Dotrina hau kokatu eta gero, Oikiako beste dotrina ezagunarekin (1759) dituen loturak ikusiko ditugu (§ 2) eta, horretarako, honen egilea (§ 2.1) eta data egiaztatuko ditugu (§ 2.2). Azkenik, emaitzok gurutzatuko ditugu (§ 3) ondorioetara iristeko (§ 4). Amaitzeko, kontsultatu ditugun artxiboak, bibliografia (§ 5) eta zenbait eranskin (§ 6) eskaintzen ditugu.

3.- Zenbait frantses edizioek lagundu zuten «eskuizkribu»aren definizio hau hedatzen eta genesi-ikerketen helburua berritzen, berrogeita hamarreko hamarkadan. Honela, eskuizkribu hitzak idazlan baten «eskuz» idatzitako bertsioez gain, aurretiko planak, oharrak, edo idazketarako bildu den dokumentazioa ere adierazten du. Dokumentu hauek izendatzeko, gerora sortu zen avant-texte edo aurretestu kontzeptua -kritika genetikoaren sortzailea eta J. Bellemin Noël-ek 1972an proposatua- eta multzoak edo aurretestuek osatzen dute genesiaren dosierra (Lluch, J., 2010, "Los estudios de génesis textual" in Arcocha-Scarcia, A. et al., 1954). Honen guztiaren azalpenak urrunegi eramango gintuzke hemen, eta bibliografiaren berri ematea ere lan honetako helburuetatik at geratzen da, baina oinarrizkoa aurki dezake irakurleak aipatu liburuan. 


\section{1.- Oikiako dotrina «berria»: Christau-ac Ezaguera arrazoizcora elduezquero Sinistu Jaquin, ta Eguin beardituan gaucen jaquin videa}

D.n Francisco Antonio Aguirre aurkezten zaigu dotrinaren egiletzat eta Oquiaco Vicario karguan, baina ez da idazkiaren urterik aipatzen:

Christau-ac Ezaguera arrazoizcora elduezquero Sinistu Jaquin, ta Eguin beardituan gaucen jaquin videa.

D.n Francisco Antonio Aguirre, Oquiaco Vicarioac atera-a, ta compondua bere contura dauzcan Animen Oneraco.

Escaintcendio Jaincoaren Ama Aingueruen Erreguiña becatarien Zaizalle Maria Santissimaren lenengo Izatearen Jatorrizco becatu gabeco sorce miragarriari.

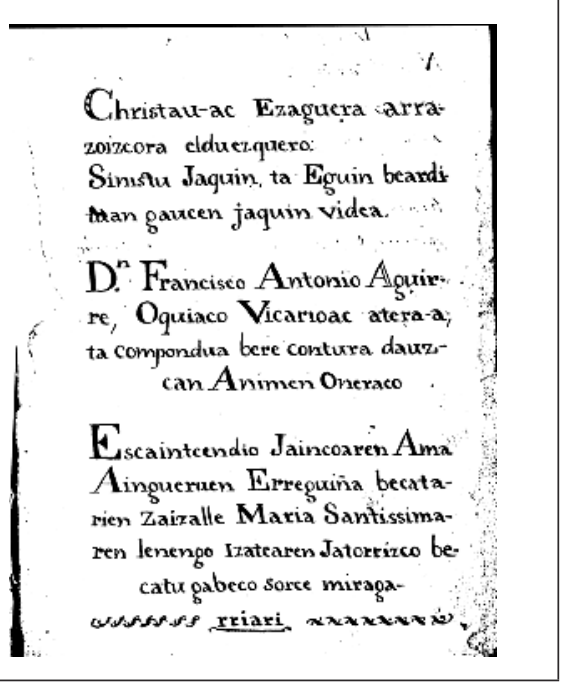

- Liburu gisa koadernatua. Azala larruzkoa eta berria, ez da jatorrizkoa. Ertzak urdinez koloreztatuak.

- 174 orri ditu idatziak eta zenbatu gabeak. Lehenengo orria zuri. Bigarren orri babeslea falta da, urratua ikusten baita. Ondotik izenburua daraman orria doa eta hurrengoa zuri dago, testua honen ondoko orrian hasten delarik.

- Papera XVIII. mendekoa da.

- Neurriak: 205 x 150. Azalak 210 x 150 x 30.

- Joskera: hari zuria, lihoa dirudi. Bost lekutan josia: ertz bakoitzean bina joskera, tarte berdintsuan, eta erdialdean bestea. Pleguak hirunaka josita daude, hots, sorta bakoitzean sei orri.

- Izenburuaren atzealdean, lehenengo orrialdean, honela hasten da: Iracurleari aurreraco videa. Bosgarren orrialdearen aurrealdean, sarreraren amaieran, honela esaten du: Ala erregugutcen [sic], esperatcen, ta confiatcen du Berorren serbitzari ta Morroiric chiquien F. A. A. ${ }^{\text {ecoac }}$.

- Honela amaitzen da: Encargattcen dizuet, oitu zaiteztela contricioco damura, cerren supittan, hitz gabe, edo confesore gabe eriotzac arttcen bagaittu, contricioa degun gure pecatuac barcattceco erremedio bacarra, ta au badegu ondo guera, confesattceco deseoarequin ta irabatcicen ditugu eriotzaco orduraco diran Buldaren, ta beste Yndulgenciac. [Azpimarra egilearena].

- Orri guztiek ur marka dute. 
- Eskuizkribuaren ezaugarriek XVIII. mendeko Oquian kokatzen gaituzte, eta D.n Francisco Antonio Aguirre bertako bikarioak idatzitako dotrina ez hain laburraren aurrean jartzen. Orduan utzita ez bezala aurkitzen dugu, azala berria baita; hala ere, eta orriak zenbatu gabe egon arren, pleguen joskerek testu osoa dagoela adierazten dute. Lehen eginbeharra datu hauek egiaztatzea litzateke, F. Antonio Agirre delakoa testuaren egile dela ziurtatzeko.

\subsection{Frantzisko Antonio Agirre}

Egileari buruzko lehenengo berriak, dotrina Frantzisko Antonio Agirrek idatzia bada behintzat, Don Julio de Urquijorengandik iritsi zaizkigu. Izan ere, gogora dezagun beste «Oikiako Dotrina (1759)» ezaguna lehen aldiz argitara ${ }^{4}$ eman zuena Urquijo bera izan zela eta dotrinaren egile gisa ere D.n Fran.co Antonio Aguirre izenekoa agertzen zaigula, nahiz eta gerok eta J. Lakarrak $(1987: 517)^{5}$ ere eskuizkribuan «Aguerre» irakurtzen dugun.

Bestalde, agertu berri den dotrina honetan D.n Fran.co Antonio Aguirre Oquiaco Vicario dela esaten da. Orobat bere bataio agirian (ikus 15. oharra) eta Loiolako Egunkarian ere «Oquina» irakurri dugu, eta ez «Oiquina» (ik. 13. oharra). Kontu hau argitzeko, alde batetik, Donostiako Elizbarrutiko Agiritegira jo dugu eta Oikiako heriotza agiriak jasotzen diren liburuan edo «libro II de finados» deritzanean, 1805eko uztailaren hogeita zazpian, hirurogeita hamazazpi urte zituela, Oikian zendu zen Don Francisco Antonio de Aguirre, eta ez Aguerre, bertako erretore izan zela esaten da:

El día veinte siete de Julio de mil ochocientos y cinco murio en la Casa Vicarial de Oyquina, de edad de setenta y siete años cumplidos (habiendo recibido la Santa Uncion) Don Francisco Antonio de Aguirre Vicario de esta parroquia: su cuerpo se enterro dia veinte y ocho en esta parroquia de Oyquina: testo ante Antonio Fran. ${ }^{\text {co }}$ de Echeverria Escrivano numeral de la villa de Zumaya y en fe de todo firme como servidor de dicha Yglesia. Fr. Jose Antonio de Ezeiza. [50. orrian] $]^{6}$.

Bestetik, Loiolako Jesulagunen Artxiboan Fran.co Antonio (Anttonio) de Aguirre izeneko batek idatzitako hemezortzi eskutitz aurkitu ditugu. Pertsona bera dela esan daiteke, ez da dudarik, guztiak Oikian idatziak eta bertako bikario moduan sinatuak daudela ikusten

\footnotetext{
4.- Revue de Linguistiquen 1905. urtean. RLPhC 1905, 249-272 eta 1906, 45-67, 102-120, 164-176. Liburu gisa, Librairie Orientale et Américaine E. Guilmoto editeur, Paris, 1906, 77 or. Urquijo liburutegian, sinadura zk. 2638.

5.- Julio de Urquijok egindako edizioa berregin zuenean.

6.- Agiri hau ez da liburuko 60. orrian jasotzen Julio de Urquijok zioen bezala, 50. orrian baizik. Bestetik, agirian Agirre zendu zen urtean 77 urte zituela esaten da, eta ez 75 , ondoren erakusten dugun bataio agirian ere ziurta daitekeen moduan.
} 
baitugu (1759-1766): eskutitz gehienak Frantzisko Anduaga anaia prokuradoreari zuzenduak dira, eta lehena 1759an idatzia da; azkena, berriz, Larramendi zendu zen urtean igorri zuen, baina jesuitak hurrengo urtean (1767an) erbesteratuak izan zirelako, hain zuzen, jadanik bai baitakigu beste hemeretzi urtez, hil zen arte, erretore izan zela Oikian.

Noiztik, ordea? Noiz izendatzen dute? Bertako semea al zen? 1759ko maiatzean hartzen du Agirrek Oikiako S. Bartolome parrokiako erretore kargua. Aiako bikarioaren laguntzaile izana da, eta Oikiako parrokiaren ardura zeraman J. Zelaiaranen heriotza dela-eta Agirre huts hori betetzera dator. Berak egiten du eskabidea, Gotzainari zuzentzen dion eskutitz honetan ikus daitekeen gisan".

Dn Fran.co $A^{\circ} t^{\circ}$ de Aguirre Presbitero natural del Lugar de Marin Obispado de Calahorra then.te que ha sido del Rector de la Universidad de Aya, Diocesis de V.S.Y. puesto a sus pies con el maior rendim.to dire que la vicaria de la Yglesia Parroquial de S.n Bartholome de Oiquina se halla vacante por muerte de Dn Jph Celaiaran su ultimo posehedor [...]; y por quanto al presente se halla tambien vacante la Rectoria de Aizarnazaval, y sobre su provission ai pleito pendiente en el tribunal de V.S.Y. entre D.n Jph Santiago de Roteta, y D.n Juan Joseph de Querejeta, y por lo mismo [...], y serlo no menos la falta de pasto espiritual que experimentan los Feligreses de Oiquina, por no tener parroco propio, [...] V.S.Y. a quien [...] en los terminos expuestos corresponde la provission de la Vicaria no toma la providencia de proveerla, ussando del d[e]r[ech]o que le corresponde: por tanto, y deseando el suplic[ante] entrar en su servicio con el beneplacito de V.S.Y.

A V.S.Y suplica rendidam.te se sirva hacerle merced y gra[cia] de d[ic]ha Vicaria de Oiquina lo que assi espera de la mucha caridad de V.S.Y. [Etzana gurea da. Ikus idazki honen hasiera 1 eranskinean].

Dokumentu berean Autoa dator, Oikiako bikario izendatuz, Gotzainaren zigiluz eta Ante mi sinatua, «Pamplona a 9 de Mayo de 1759, Dr. Dn. Jph. Eladio Collado»:

En vista de este memorial, hacemos gracia y merced a D.n Fran.co Antonio de Aguirre suplicante de la Vicaria de la Yg[lesi]a de S.n Bart[olo]me del Lugar de Oyquina de este Obispado vacante p[or] muerte de D.n Jph Celaiaran, [...] p [or] los motibos q[u]e expresa este memorial, q[u]e son publicos y notorios; y mandamos [...] se le despache titulo, colac[io]n y canonica Ynstituc[io]n de d[ic]ha Vicaria [...] p[ar]a q[ue] la goze todos los dias de su vida. Y

7.- Hala nola: Oiquina Jul.o de 1759, Fran.co Antt.o de Aguirre. Oiquina Jul.o 20 de 59, Fran.co Antt.o de Aguirre. Oiquina 11 de Agosto de 1759, Fran.co Antt.o de Aguirre. Oiquina feb.o 26 de 1761, Fran.co Antt.o de Aguirre. Oyquina año de 1761, D.n Fran.co Antonio de Aguirre Vicario. Oiq.a Feb.o 6 de 1763, Fran.co Antt.o Aguirre. Oiquina Feb.o 24 de 1763, Fran.co Antt.o de Aguirre. Oiquina Oct.re 5 de 1764, Fran.co Anttonio de Aguirre. Oyquina, 1765, Fran.co Antt.o de Aguirre. Oiquina, Enero 18 de 1765, Fran.co Antt.o de Aguirre. Oiquia Abril 12 de 1765, Fran.co Antonio de Aguirre. Oiquina Maio de 1765, el tocaio Aguirre (esan bezala, Loiolako prokuradoreak Frantzisko izena baitzuen). Oyquina 15 de febr.o de 1766, Fran.co Antt.o de Aguirre. Oyquina, 28 de Nov.re de 1766, Fran.co Antt.o de Aguirre. Oyq.a 18 de Diz.re de 1766, Fran.co Antonio de Aguirre eta Oyquina y Diz.re 27 de 1766. Fran.co Anttonio de Aguirre.

8.- Eskutiz hau eta ondoko agiria ere Iruñeko Elizbarrutiko Agiritegian aurkitu ditugu. 
p[or] este n[uest]ro auto assi lo provehimos y mandamos en Pamplona a 9 de Mayo de 1759. [Ikus 1 eranskina].

Izendapenaren aitormena jasotzen duen agiria dugu honakoa, 1759ko maiatzaren hamaikan:

En la Causa y pleito que pende ante nos sobre la Vicaria de la Yglesia Parrochial de San Bartholome de Oiquina anexa a la Parrochial de San Miguel de Aizarnazabal que se alla Bacante por fín y muerte de D.n Joseph Zelaiaran su ultimo Poseedor y tocando su nuevo nombram[ien] to [...] hacer gracia y m[e]r[ce]d de dicha Vicaria por su auto de nuebe del corriente Mes de Maio a Dn Fran.co Antonio de Aguirre Presvitero en cuio nombre [...] su Pror pide se le adjudique dicha Vicaria con sus frutos y rentas desde la bacante haciendole institucion y Colacion Canonica de ella; y a su favor se despache título en forma, para que la pueda serbir y gozar durante su bida; Vistos los autos=. Fallamos atento los autos y meritos del proceso y lo que de el resulta que debemos de adjudicar y adjudicamos la sobre dicha Vicaria de la Parrochial de San Bartholome de Oiquina anexa a la de San Miguel de Aizarnazabal con todos sus Frutos y rentas desde la Bacante al nominado; D.n Francisco Antonio de Aguirre, como a nombrado por dicho Iltmo Señor obispo de este obispado [...] ya sido examindao ya probado [...] por los Examinadores Sinodales de este obispado por dicho Iltmo Señor obispo nombrados y en nuestra presencia y que concurren en el los demas requisitos necesarios le hacemos Colacion y Canonica institucion de dicha Vicaria por inposicion de un Bonete en su cabeza y mandamos despachar a su fabor título en forma para que la pueda serbir y gozar durante su bida; y por esta nra Sentencia asi lo pronunciamos mandamos y firmamos = Lizenciado Canal=.

Ondoren, Francisco Alejo de Espoz Iruñeko notarioak ziurtatzen eta sinatzen du:

En la Ciudad de Pamplona y en la posada del S.or Lizenciado D.n Manuel de la Canal Prov.or y Vicario General de este obispado a onze de Maio de mil setecientos cinquenta y nuebe: su merced pronuncio y declaro esta Sentencia segun y como en ella se contiene en ausencia del Pror de la Causa y de ello y su pronunciacion mando hacer autto a $\mathrm{m}=$ Fran.co Alejo de Espoz Notario=

Azpian: Por tras.do por el secr. ${ }^{\circ}$ Alm [ando]z. Juan Antonio de Gorostidi Not. ${ }^{\circ} .9$

Agiri hau idazteko erabili zen paperaren ur marka ( $(1.3)$ aztertu ondoren, papera 1758an ekoitzi zela jakin dugu. Honek jatorrizko dokumentua dela adierazten digu, hots, ez gaude dokumentu faltsu baten aurrean eta, ondorioz, izendapenaren urtea, 1759, egiaztatzen digu.

Iruñeko Elizbarrutiko Agiritegian Aita Sales artxibozain adeitsuak milaka fitxaren

9.- Gorostidi Getariako notarioa zen urte haietan. 
artetik atera zigun honakoan ere, laburbilduz, hitz hauek irakurtzen ditugu ${ }^{10}$ :

Oiquina aneja Aizarnazabal 1760. Vicaria vacante en la parroquial de Oiquina, por muerte de su poseedor, D. Joseph de Celayaran. La provision toca al Sr. Obispo por estar vacante la rectoria de Aizarnazabal y su Ilustrisima la provee en Dn. Fco Ant ${ }^{\circ}$ de Aguirre presbitero natural de Marin, Obispado de Calahorra a quien es adjudicada. [Etzana gurea $\mathrm{da}$.

Datan urtebeteko aldea dago hemen (1760), baina Agirrek berak Loiolara idazten duen lehen gutunak, aurrean aurkeztu dugun agiriak eta egin dugun paperaren azterketaren emaitzak 1759an izendatua izan zela frogatzen dute ${ }^{11}$.

1759ko maiatzean izendapena jaso eta irailaren 14an ikusten dugu lehenengoz Oikiako erretore gisa heriotza aktak sinatzen ${ }^{12}$ :

El dia catorce de Septiembre de mil setecientos y cinquenta y nuebe, recividos los Santos Sacramentos murio en Guetaria Ana Maria Eznal, y dispuso enterrarse en esta Iglesia donde fue enterrada el dia quince, no testo, y como vicario propietario de esta Parroq[uia]l de S.n B[artolo]me de Oiquina firme =

D.n Franc.co Anttonio de Aguirre. [Ikus 2 eranskina]

Lehenago Loiolan aurkitzen dugu, aurrean aipatu bezala (ikus 7. oharra eta 3, 4 eranskinak), bertako Agiritegian topatu ditugun hemezortzi gutun horietatik lehena 1759ko maiatzaren hogeita bostean idatzi baitzuen, hau da, erretore kargua hartu berritan, eta iraila aurretik beste hiru igorri zituen bere izendapenaren berri emanez eta Loiolako jesuiten harrera eskertuz:

Mui S[eñ]or mio: Aprecio a VR. su buen afecto y voluntad que me hace favor de manifestarme en la que acabo de recivir, y igualmente me ofrezco el t [iem]po q[u]e durare mi residencia en esta, y s[iem]pre a la disposiz[io]n de VR. para que en el espresado aprecio y en el que rever.te ostento a su profes.n funde una entera confianza a mandarme. [...] al R. P.e R.r a cuia ob.a y de essa S[an]ta Casa se servira VR. presentarme. N[uest]ro S[eño]r g[uard]e a VR. mu[cho]s añ[o]s. Oiquina Maio 25 de 59. M.a VR. su m.or serv.dor Franc.co Antt.o de Aguirre. Herm[an]o Fran.co Anduaga, mui S.r mio.

Mui S[eño]r mio, y mi espez[ial] favorecedor. Recivo su estim[a]da carta con la de recomendacion, y instruccion de la que doi a vm las correspond[ien]tes gra[cias] y me valdre de ellas en prim[er]a ocas[io]n. No se q[ua]l ha sido el motivo o fundam[en] to de n[uest]ro Itt.o p[ar]a esta provis[i]on, pues me hizieron examen sinodal, y me dieron titulo en forma, en

10.- Almandoz C/ 1982 - No 17. Elizbarrutiko epaitegiko idazkaria da Almandoz. Bestalde, Agiritegi berean Agirreren berri beste dokumentu honetatik ere jaso dugu: «(1783-1828) Plan Beneficial de la parroquia de Guetaria. Dirige el proceso informativo F.co Ant.o Aguirre, Vicario Oiquia», Villar c/2757- № 1 .

11.- Urteak ziurtatzea, bada, ez dela alferrikako lana agerian da.

12.- Oikina. Parroquia San Bartolomé, Libro II de Finados, 23. orrian. 
vista de la gr[aci]a de S.I. circunstanz[ia]s son q[u]e no assiten p[ar]a interinato, [...] y a toda essa S[an] ta Casa reitero mi rend.da ob.a con la que pido a Dios me le g[uard]e mu[cho]s añ[o] s. Oiquina Jul [i]o de 1759. Franc.co Antt.o de Aguirre.

Iduri luke, bada, jesuitekin harreman estuak izan zituela Agirrek; ez da harritzekoa ere, Oikiara misioak egitera jesuitak joaten baitziren. Loiolako Ikastetxeak urtero zortzi eguneko misioa egiteko betebeharra zuen kostaldeko herrietan eta Zumaian egiten zenean, bost egun bertan eta hiru Oikian egiten ziren ${ }^{13}$. Ez dakigu, bestalde, Agirrek zuzenean Aita Kardaberazekin harremanik izan zuen, berari idatzitako eskutitzik ez baitugu aurkitu, baina eskuetan ditugunen artean, behin baino gehiagotan hura agurtzen eta haren lanen eskaria egiten ikusten dugu (Christavaren vicitza, Christauaren Doctrina, Egercicioac, Justuen Ispillu Arguia, Senar emazte santuac...). Hona hemen zenbait pasarte interesgarri:

Mi estima[a]do P.e Fran[cis]co. No he tenido la honrra [...], mi respeto al R. P. Ag[usti]n [Cardaveraz] y dem[a]s P[adre]s, y mande [...]. Oiquina Oct.re 5 de 1764. Fran.co Anttonio de Aguirre.

Mui S[eñ]or mio: Agradecido al favor [...]. Los $59 \frac{1}{2}$ r reale]s y Libros son p [ar] a el P[adr] e Agustin [Cardaveraz], o Herm[an]o [...] los r[eale]s son importe de 20 libros de Exercicios, y de trece de Christavaren vicitza, q[u]e al cavo de tres o quatro años se han despachado en Zarauz. Vm.

13.- Honela irakurtzen dugu Loiolako Egunkarian: «Este Colegio tiene obligación de hacer todos los años ocho dias de mision en los lugares de la costa, que pertenecen a este Obispado, que son, Orio, Zarauz, Guetaria, Zumaya, Deva y Motrico: en Aya se ha hecho alguna vez, por no menudearse en los lugares sobre dichos, y por reputarse, como lugar de la Costa por la cercania a ella. En Deva se hace esta mision de dos a dos años y en los demas se va alternando; pero cuando toca a Zumaya, cinco dias se hacen en este lugar y tres en Oquina».

1755ean, Agirre Oikiara joan aurretik, Zumaian eta Oikian egin ziren misioen berri ematen da Egunkari honetan: «Misión de Zumaya de 7 a 7 años. Los PP. Juan Bautista de Renteria sujeto de este Real Colegio y el P. José Gorriz predicador de la Residencia de Azcoitia, predicaron en la Villa de Zumaya de[s]te año de 1755, doce dias de Misión, empezando el dia 18 de setiembre hasta 29 inclusive. Los mismos PP. predica[ron] en Oquina cinco dias, desde el 1 de Octubre hasta el cinco, pero se advierte que no hay obligación de predicar en Oquina sino tres funciones» [141. or.].

1760an Debako misioen zehaztasunak jasotzen dira: hamabost egunekoak egin ziren eta Pedro Zabala eta Ignazio Arizaga izan ziren misio lanetan aritu ziren jesuitak. Ondoko urtean, 1761ean, Getarian eta Aian izan ziren hamabi eta hamabost eguneko misioak ematen.

1764an Oikian egin zirela Agirre berak ere esaten digu, Loiolara urte bereko urrian idatzitako eskutiz baten bitartez. Misiolariak Pedo [Zabala] eta Ygnacio [Arizaga] jesuitak izan zirela ere egiaztatzen du: «Mi estim[a]do Fran[cis]co. No he tenido la honrra, q[u]e me ofre... VR de assistir a los P[adre]s Pedro y Ygnacio en $\mathrm{q}[\mathrm{u}] \mathrm{e}$ tendria mi maior gloria, pues se han escusado, diciendo se hallan proveidos de todo, y mejor de lo q[u] e esperaban, siento no aver tenido ocas[i] on de servir pero me consuelo en las circunstanz[i]as de q[u]e me hallava ignorante, esten gustosos. Mañana [...] las ocupaciones y faltas de Cav.a me han impedido la assist[en]cia a la S[an]ta Mission. Aun no han venido [...] mi respeto al R. P. Ag[usti]n y dem[a]s P[adr] es, y mande [...]. Oiquina Oct.re 5 de 1764. Fran.co Anttonio de Aguirre».

Loiolako Egunkarian honela esaten da: «El P. Pedro Zabala hizo mission 3 dias en Oquina por Octubre de 1764 por oblig[acio]n de este Col[egi]o de Loyola. El P. Pedro Zabala y el P. Ygnacio de Arizaga hizieron 12 dias en Zumaya por oblig[acio]n de este R[ea]l Col[egi]o de Loyola, y ambos lugares son del O[is]pado de Pamplona, y ambas misiones se hizieron por Octubre de 1764». 
mandeme en q[uan]to me considerasse actual servidor, pues quedo Rog[an]do a D[io]s me le g[uard]e m[ucho]s añ[o]s. Oiquina Maio de 1765. El tocaio Aguirre. Mi P.e Fran.co Ant.o Anduaga.

Joseph, y mui S[eño]r mio: Recivi la apreciable de Vm. con toda estimacion, llame al Inquilino de Lasalde, [...] y perdonandome la molestia, tambien puede Vm. remitirme con la q[u]e llevasse esta las 4 ptes de Exercicios bascongados, la vida de S. Isidro y demas traducc[ione] $s$ del P. Agustin C.MB menos la Vida Christiana, y Astete, q[u]e ya tiene con las vidas de S. Luis y S. Estanislao el q[u]e los quiere. Al P.e R.or mis resp.s y express.s a P. Franc.o [...]. Quedo p[ar]a servir a Vm. [...] gocen Vms. felices Pasquas y dem[a]s festiv[o]s, y Ruego a D[io]s les G[uard] e m[ucho]s añ[o]s. Oyq.a 18 de Diz[iemb]re de 1766. Fran.co Antonio de Aguirre.

Padre Jph, y mui S[eño]r mio: Recivi la apreciable de Vm [...] doy a Vm las mas atentas gracias, y espero [...] q[u]e se dignara passar mis atentas expres[ione]s al P.e Fran.co [...] Oyquina y Diz[iemb]re 27 de 1766. Fran.co Anttonio de Aguirre. Al P. Ag[usti]n [Cardaveraz] mis B.os y esp [er] o sus traducciones y obras bascongadas, si ai arbitrio me aplique su importe en [...]. [Etzanak gureak].

Agirreren hitzak, besteak beste, garai honetan Kardaberazen lanek izan zuten zabalkundearen lekuko dira, artekari gisa ere ibili zela bai baitirudi ${ }^{14}$.

Azkenik, Agirreren heriotza agiria jasotzen den orrialde berean, 1804ko abenduaren 17an hil zenaren berri ematen aurkitzen dugu Agirre bera, jadanik letra makurrez, gaixotasunaren aitorle. (Ikus 5 eranskina).

Beraz, F. Antonio Agirre 1759ko maiatzetik 1805eko uztaila arte izan zen Oikiako S. Bartolome parrokiako erretore. Datu hau ezagututa, bere jaioterria argitzea litzateke hurrengo eginbeharra. Jadanik goian azaldu ditugun agirietan Dn Fran.co Ant ${ }^{\circ}$ de Aguirre Presbitero natural del Lugar de Marin Obispado de Calahorra irakurri dugu. Bertako elizako liburuetara jo dugu eta bertan Francisco Antonio de Aguirre Gaviriaren izena aurkitu dugu. Azpian, beste tinta batez idatzia, «cura vicario perpetuo de Oquina, Obispado de Pamplona» esaten da. Argi dago, bada, bila genbiltzan bataio agiriaren aurrean aurkitzen garela ${ }^{15}$ :

En tres de S[eptiemb]re del año de mil setecientos y veinte y ocho, Yo D.n Pedro Ygnacio de Aristi beneficiado de la Parroq[uia] de Salinas, y cura de esta de Santa Maria Magdalena de Marin bautice a un niño al qual se le puso por nombre Francisco Antonio, nacio a las siete de la tarde de dia dos

14.- Kardaberazen Christavaren vicitza 1765eko eta 1766ko gutunetan aipatzen du, «q[u]e al cavo de tres o quatro años se han despachado en Zarauz»; lehenengo argitalpenak ez ezik bigarrenak ere sona handia izan zuela, bada, agerian da. Hona Kardaberazek berak ere Jesus, Maria ta Joseren Devocioa... lana argitaratzeko baimen eske dabilela, egiten duen aipamena: «[...] Hace muchos años saqué en bascuence la Vida Christiana, sacada o tomada de P. Dutari, siendo Provincial el P. Zárate. Se acabó la impresión, y por las instancias que muchos me hacen, pienso recurrir al P. Provincial para la reimpresión. Deseo que con su licencia se inserte al fin del librito el mismo Cartapacio 10 con las Novenas a nuestro Santo Padre y San Xavier, en bascuence» in Telletxea Idigoras, J.I. (ed.), 1990, Obras de Padre Manuel de Larramendi, IV: Escritos Breves, Donostia: Sociedad Guipuzcoana de Ediciones y Publicaciones, 303.

15.- Donostiako Elizbarrutiko Agiritegian, Parroquia de Marin (2) A.1-2 liburua, 87. orrian. 
del d[ic]ho mes, hixo legitimo de D.n Juan Miguel de Aguirre Gaviria, y D.ña Maria Francisca de Segura = abuelos paternos D.n Diego de Aguirre Gaviria y D.ña Cathalina de Ascoaga, abuelos maternos D.n Juan Asensio de Segura y D.ña Antonia de Lacristegui, vecinos dela ante Iglesia de Goronaeta = Fueron padrinos D.n Diego de Aguirre Gaviria su abuelo vec[ino] de este d[ic]ho lugar, y D.ña Antonia de Lacristegui vezina del lugar de Goronaeta, y por ser verdad firme, y advertiles el parentesco espiritual que contraxeron =

D.n Pedro Ygnacio de Aristi.

1728ko irailaren bian jaio zen F. Antonio Agirre Gabiria Segura, eta Eskoriatzako Marin auzokoa zela egiaztatzen dugu. Aita, Juan Migel Agirre Gabiria, bertakoa zuen eta ama, Maria Frantziska Segura, Goronaetan jaioa. Julio Urkixok ere ez zuen uste Agirre Oikian jaio zenik, baina ez zuen gehiago argitu edo argitzerik izan. Orain, bada, gehixeago dakigu F.A. Agirrez; gaur arte, dotrinaren hasieran irakurtzen denaz gainera, heriotza agiritik jasotako berriak besterik ez baikenituen ezagutzen (ikus 6. oharra).

Heriotza agirian aipatzen den testamentura ${ }^{16}$ jotzen badugu, berriz, «D.n Francisco Antonio de Aguirre Gaviria» deitura dakusagu, amarena aipatzen ez delarik. Memorialak lau orri hartzen ditu (127r-130r) eta hirugarrenean amaitzen da (1801-07-20), baina azkeneko orrian (130r) lerro batzuk gehitzen dira aldaketa baten berri emanez: aurreko memoriala bukatu ostean Agirreren iloba bat hiltzen da, D.n Juan Eusebio de Aldazaval (Aozarazako apaiza), eta bere izenean utzitako ondasunak beste iloba baten esku uzten ditu (1804-0727).

Testamentu honetatik berri ugari jasotzen dugu: Frantzisko Antonio Agirre Gabiria Segura, Juan Migel Agirre Gabiria eta Maria Frantziska Segura senar-emazteek izan zituzten bost seme-alabetatik gizonezko bakarra eta zaharrena zen. Agiritegietatik jaso ditugun datuen arabera, lau arreba hauek izan zituen: haurtzaroan zendu zen $\mathrm{M}^{a}$ Isabela (1730-1119), Ma Catalina (1733-04-21), Francisca (1735-08-03) eta $M^{a}$ Assumpción (1739-02-02). Testamentuan esaten denez, azken hau, $\mathrm{M}^{\mathrm{a}}$ Assumpción, moja zen eta Soraluzeko komentuan zegoen ${ }^{17}$. Testamentuan ez da, jakina, $\mathrm{M}^{\mathrm{a}}$ Isabela arrebaren berririk ematen eta hirugarrengo arrebaren izena ere ez da aipatzen, biak Maringo elizako liburuan aurkitu ditugu.

Senide guztiak Frantzisko Antonio izan ezik, Juan Bauptista Agirre Gabiriak, osabak, bataiatu zituen. Bera 1704ko ekainaren hogeita lauan jaio zen ${ }^{18}$ eta 1729an Maringo parrokiaren ardura hartzen $\mathrm{du}^{19}$, F. Antonio jaio ondorengo urtean. 1774ko irailaren batean zendu zen. F. Antoniok ezin izango zuen, bada, bere sorlekuko bikario izan, hamabost urte lehenago Oikiakoa izendatu zutenean.

16.- Gipuzkoako Protokoloen Artxibo Historikoan, signaturatzat 2/2177 zenbakia daraman liburua.

17.- Honen bataio agirian, bere amona D. a Cathalina de Ascuaga zela esaten da («vecina de dicho lugar y natural de la anteiglesia de Azcoaga»), eta ez Ascoaga, Frantzisko A. anaiaren bataio agirian irakurri dugun gisan.

18.- Aurreko urtean (1703an) jaio eta berehala hil zen anaiaren izena jarri zioten: «Juan Bauptista Aguirre Gaviria, murió siendo parbulo [...]».

19.- Donostiako Elizbarrutiko Agiritegian, Parroquia de Marin (2) A.1-2 liburua, 22. orrian: «Juan Bauptista de Aguirre Gaviria. Partida del cura y beneficiado actual del año de 1729 en q[ue] ha entrado a servir [...]». Lehenengo bataio agiria 1729ko abuztuaren hogeita zortzian sinatzen du. 
Beste senitartekoen artean, F. Antonio Agirrek sei iloba, osaba bat (D.n Gabriel Agirre Gabiria) eta bi lehengusuren berri ere ematen digu testamentuan. Bi lehengusu hauek ere apaizak ziren: D.n Apolinar de Madina («cura y beneficiado de la Parroquial de Marin») eta D.n Carlos de Segura («cura y beneficiado de la Parroquial de Goronaeta»). Ikusten denez, gurasoen eta bere jaioterriko elizak familiartekoen ardurapean ziren. Beste bi iloba ere erlijiosoak zituen: D.n Juan Eusebio de Aldazaval («cura y beneficiado de la Parroquial de Aozaraza en el Valle Real de Leniz») eta D.a Josefa Antonia de la Santissima Trinidad («Religiosa en el convento de Mendaro»). D.n Juan Eusebio apaizaren anaia, Gabriel Jacinto Aldazaval, izan zen gurasoen etxean gelditu zena: «[...] mando a mi sobrino D.n Gabriel Xacinto de Aldazaval y su Esposa D.a Dominica de Gerica el agua benditera [...] y renuncio a su favor todos los derechos que me competen a los bienes libres de mis Padres, como tambien [...]». Gabriel Jacintok eta Juan Eusebiok arreba bat zuten: $\mathrm{M}^{\mathrm{a}}$. Manuela Aldazaval. Agirreren beste bi ilobak $\mathrm{M}^{\mathrm{a}}$ Santos Zavala eta Eusebia Zavala ziren. Hauen ama da, Frantziska, Agirrek testamentuan aipatzen ez duena; seguruenik, bada, memoriala egin zuenerako, 1801erako, hila zela. Ma Santos Oikian egon zen Agirrerekin eta bere oinordeko izendatzen du:

Y cumplidas todas las mandas y legados de este Memorial, y mi testamento, instruio y nombro por mi universal Heredera en todo el resto de mis bienes, derechos y acciones havidos y por haver a mi d[ic] ha sobrina D.a Maria Santos de Zavala en atencion al cuidado, diligencia, y especial afecto, con que me he servido largos años, para que las goze, y disfrute con la bendicion de Dios, y la mia.

Labur esateko. Frantzisko Antonio Agirre Gabiria Segura, Maringo Juan Migel Agirre Gabiria eta Maria Frantziska Segura Goronaetako alabaren semea zen. Bost senidetatik zaharrena eta gizonezko bakarra. 1728ko irailaren bian jaio zen Gipuzkoako Eskoriatzako Marin auzoan, eta hurrengo egunean D. P. Ygnacio de Aristik bataiatu zuen, bere arrebak ez bezala, ondoko urtean bere osabak hartzen baitu Maringo elizaren ardura. Apaiz ikasketak egin eta Oikiara joan aurretik Aia herrian egon zen, bikarioaren laguntzaile. 1759ko maiatzean, hogeita hamaika urte zituela, Oikiako parrokiako bikario izendatzen dute eta kargu honetan iraun zuen bere bizitzako azken egunera arte, bertan hil baitzen 1805eko uztailaren hogeita zazpian, hirurogeita hamazazpi urte zituela. Berrogeita sei urtez izan zen, bada, Oikiako erretore.

F. Antonio Agirre nor genuen jakin ondoren, bi urrats nagusi ditugu emateko: dotrinaren egile dela egiaztatzea litzateke lehena; hala bada, zein urtetan idatzi zuen aztertzea genuke bigarrena.

\subsection{Christau-ac Ezaguera arrazoizcora elduezquero Sinistu Jaquin, ta Eguin beardituan gaucen jaquin videaren egilea}

Dotrinaren sarreran eta izenburu honen ondotik D.n Francisco Antonio Aguirre, Oquiaco Vicarioac atera-a, ta compondua bere contura dauzcan Animen Oneraco irakurtzen dugu. Lehen hurbilketa honek autografoaren kontua abiaburutzat edo lanaren hipotesi gisa hartzera 
behartzen du eta Balduinok nabarmentzen duen bezala (1979: 249-250) ${ }^{20}$, ardura handiz egiaztatu behar da ziur egilearenak berarenak izan daitezkeen idatzi pribatu edo eskutitzekin alderatuz.

Oikiako elizako liburuetan ditugun bikario honen idatzietako letra mota, euskarazko dotrina honetan agertzen denarekin, erkatzeko modua eskura dugu jada. Era berean, Loiolako Jesulagunen Artxiboan 1759tik 1766. urtera, «Oyquina, D.n Fran.co Antonio de Aguirre Vicario», «Oiquia, D.n Fran.co Antonio de Aguirre» edo «Oyquina, el tocaio Aguirre» eran sinatuak aurkitu ditugun hemezortzi eskutitzetan ikusten dugunarekin ere.

Emaitzen arabera, ezin dugu zalantza izpirik izan: idazki horietan ikusten den letra eta dotrinan agertzen dena bat bera dira. Bestetik, Agirre 1759. urtetik 1805. urtera arte izan zela Oikiako erretore ziurtatu dugu eta dotrina hau, orain ikusiko dugun gisan, epealdi horretan kokatzen da. Ondorioz, Frantzisko Antonio Agirre eskoriatzarra dugu, dudarik gabe, dotrina honen egilea. Baina zein urtetan idatzi zuen? Ikus dezagun.

\subsection{Christau-ac Ezaguera arrazoizcora elduezquero Sinistu Jaquin, ta Eguin beardituan gaucen jaquin videaren urtea}

Agirrek dotrina hau zehazki noiz idatzi zuen ez du aipatzen, baina garai horretan Oikiako bikario zela esaten du. Orain jakin badakigu berrogeita sei urte igaro zituela kargu horretan (1759-1805) eta bere egiletasunaz zalantzarik ez dugunez, honek guztiak XVIII. mendeko bigarren erdian idatzitako testua dugula aditzera ematen digu, hots, 1759 ondoan egina dela. Nolanahi ere, denboran zehatzago kokatu nahi dugu, kontuan izanik, gainera, ia mende erdi bateko epeaz hitz egiten ari garela. Horretarako, kodikologiak eskaintzen duen metodoa ezarriz, Agirrek dotrina idazteko erabili zuen papera aztertuko dugu.

Edozein testu datatzeko orduan hartu ohi diren baliabideen artean, nagusiena papera bera aztertzea dela genioen «Paperaren ur markak» lanean (Segurola 2001), eta paperaren kanpoko ezaugarrien artetik (formatua, vergeure edo verjura, pontuseaux edo corondeles eta ur marka), garrantzitsuena ur marka dugula, papergilea, jatorria, paperaren formatua edo kalitatea eta urtea adierazteko ere erabili izan delako. Hortaz, honek lagunduko digu, beste ezaugarriek baino zehatzago, paper hartan idatzitako testua noizkoa den jakiten ${ }^{21}$.

Hau guztia kontuan izanik, eskuizkribua ireki eta paperak banan-banan aztertu ondoren, hona aurkitu ditugun ur markak:

20.- Manuale di Filologia Italiana, Firenze: Sansoni.

21.- Ondoko deskribapena egiten du Javier Alvaradok ere, ur marken erabileraz: «También se han empleado [las señales o marcas] para consignar la autoría de las manufacturas; por ejemplo, en las piezas de alfarería, [...] los impresos, las marcas de agua en el papel, la metalurgia [...]; para probar propiedad del objeto marcado [...]» (2009: 9). «Era costumbre o norma que el maestro papelero signara cada papel con una marca doble o sencilla que diera fe de la calidad y procedencia de la manufactura. Tales marcas de agua o filigranas eran generadas mediante el entrelazamiento de un fino hilo de cobre situado en el fondo del molde junto a la malla de corondeles y puntizones» (2009: 156). Argibide gehiago nahi izanez gero, ikus gure ondoko lana: Segurola 2001. 


\section{- FIN 1773 M J MONIE BIGORRE}

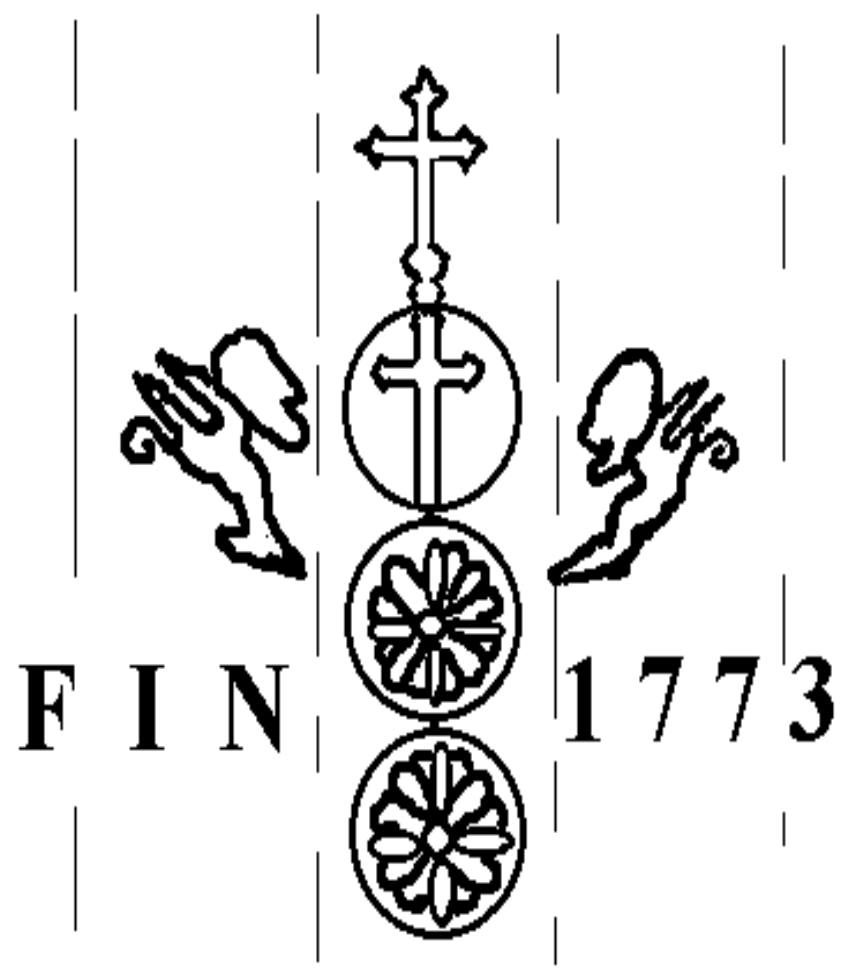

M $\quad$ । J $\quad$ M 
- FIN 1774 M I MONIE BIGORRE

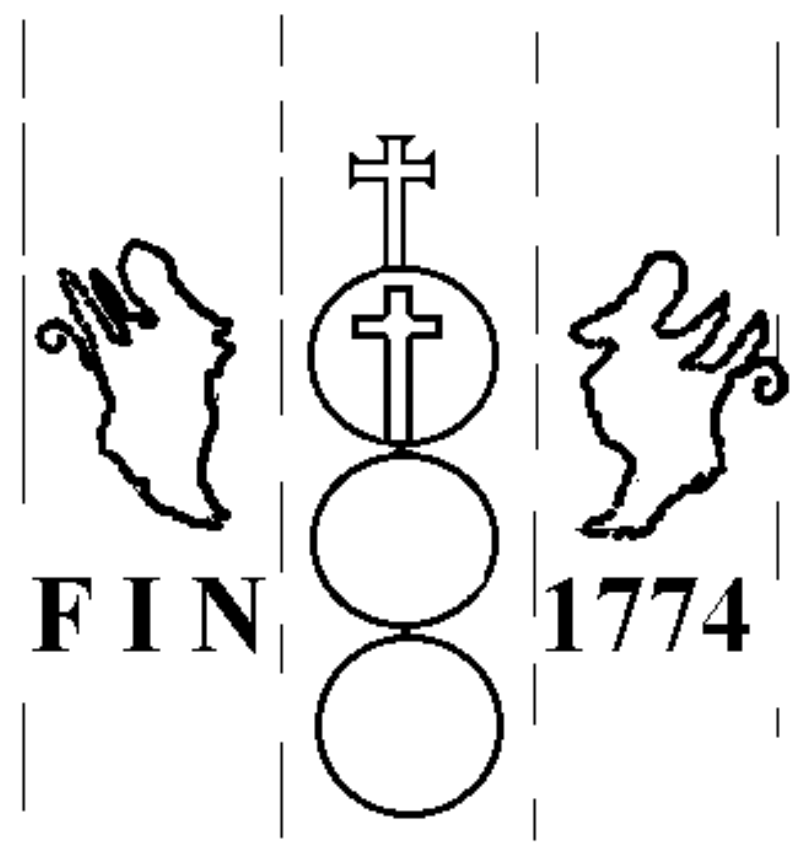

M

I MONIE

B I G O RRE 


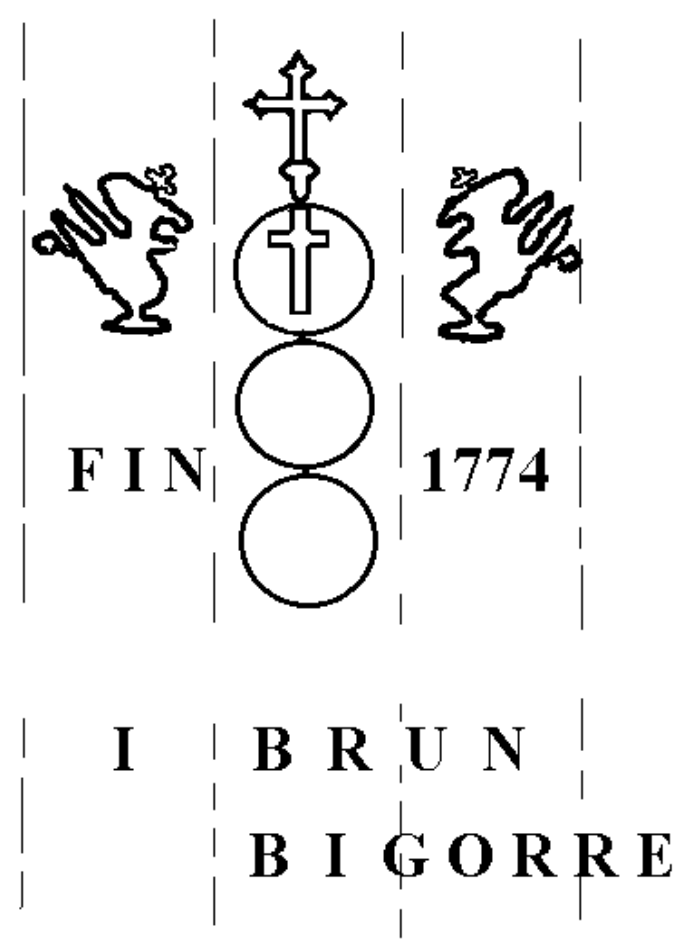

Lehenengo orri zuri edo babesleak M I MONIE marka darama. Bigarrena, berriz, falta da.

Ur marken irakurketatik datu adierazgarriak jaso ditugu:

1. Dotrina gutxienez 1774 an idatzi zuen, ez lehenago

1773an eta 1774an ekoitzitako papera erabili zuen eta, beraz, idazkia ezin da lehenagokoa izan. Ez zen 1773an ere idazten hasi, urte horretako paperak hurrengo urtean ekoitzitakoekin tartekatuak baitaude, hau da, ez doaz ekoitzitako hurrenkeran eta lehenengo berrogeita hamar orriek, behintzat, 1774ko ur marka baitaramate. Pleguak apailatu eta egokitu ziren bezala, bada, josi zituen. Hori dela eta, dotrinaren eskuizkribu hau ez dela 1774 baino lehenagokoa ziur esan dezakegu. 
2. Papera Bigorran ekoitzia da. Ur marketan ageri den gaia (hiru $O$ gisa ezagutzen dena) arrunta da XVIII. mendean lurralde honetan ekoitzitako paperetan ${ }^{22}$.

3. Ur markak urtea eta paperaren jatorria ez ezik, papergilea adierazteko ere erabilizirela agerian dugu, ondoan irakurtzen diren M I MONIE eta I BRUN deiturak bi ekoizlerenak baitira. Guk ditugun datuen arabera, Jean Monié eta Jean Brun papergileak maisuak ziren lanbide honetan. Hala izendatuak agertzen dira 1774an, hain zuzen, Maurelon, Bergès, Bonasse, Jean Camon, Jean Casaux, Guillaume Mirande eta beste papergile maisuen artean. Brun familiak Biarnoko Mirepeix-en ere bazuen paper-errota eta Biarnon egiten ziren paperen artean, Sarrance-koekin batera, onenetakoak omen ziren. Biarnoko merkatari baten bidez paper hauek Iruñera ekartzen ziren. Jaso ditugun datuetan oinarrituz, errota hau 1781 arte, behintzat, lanean aritu zen. Jean Monié Bigorrako Soues-en zegoen errotako ekoizlea zen. Hemen egiten zen papera Espainiara saltzen zela Baionako manufaktura-sailean jasotzen diren datu hauek ziurtatzen digute: errota honek 1774an 1.992 resma ${ }^{23}$ saldu zituen Espainiara,

Ur marken azterketak egilea egiaztatzeko aukera ere eskaini digu, 1774an Agirre erretore baitzen Oikian. Kargu honetan hamabost urte zeramatzala eta berrogeita sei urte zituela idatzi zuen dotrina. Hau guztia ulertzen da paperaren erabilera egin zen garaikoa dela pentsatuz, hau da, papera bere erabilerarako behar zenean erosi zela, egin zenetik denbora laburrera eta, beraz, papera eta idazkia garai berekoak direlako ustean, eskuarki gertatzen den bezala. Eskuizkributik jaso ditugun datuek, paperaren erabilerari dagokionez, gutxienez urtebeteko epea markatzen dute (1773-1774), eta nabarmendu nahi dugu honelakoetan lagungarri gerta daitekeela, edo zenbaitetan erabakigarri, paperen joskera edo joskeraren hurrenkera ere aztertzea, honek idazketaren genesia agerian uzten baitu, Agirrerenean ikus ahal izan dugun moduan.

Laburbilduz esan dezagun, gaur aurkezten dugun Christauac Ezaguera arrazoizcora elduezquero Sinistu Jaquin, ta Eguin beardituan gaucen jaquin videa izenburutzat daraman dotrinaren eskuizkribua, Eskoriatzako Marin auzokoa genuen Frantzisko Antonio Agirre Gabiriak idatzi zuela Oikian, gutxienez 1774. urtean.

Honek guztiak Agirrek idatzi zuen bigarren dotrinaren aurrean gaudela adierazten digu, baina hau egiaztatu beharra dago. Norbaitek galdegin lezake, halere, «baina Oikiako Dotrina ezaguna ez al zen bada 1759. urtean idatzi, egilearen hitzetan irakurtzen den gisan?»

22.- Ur marken diseinu geometrikoei buruz, honela dio Alvaradok: «[...] respecto a los diseños geométricos de tales marcas de agua, lo cierto es que estos sí coinciden temporalmente con los temas geométricos de los impresores (y de otras corporaciones de oficio) lo que demostraría la existencia de un mismo lenguaje simbólico artesanal en Europa a partir de la Baja Edad Media» (2009: 155). «[...] el sistema de retícula cuadriculada previa como método de trabajo, pudo facilitar la transferencia de la costumbre de las marcas geométricas de los maestros de obras a los fabricantes de papel» (2009: 157). Geometria-markarik zaharrenen artetik, gurutzearen gaia -mundu bola edo zirkuluaren gainean- gailentzen da. Hona Alvaradok dioena horren esanahiaz: «[...] al igual que en otras corporaciones, representa la devota labor del artesano que, bajo la advocación de la Cruz, trabaja en la fabricación del papel para contribuir a la fortaleza de la fe, es decir, a la gloria del Señor. [...] el círculo se asocia también al simbolismo del Sagrado Corazón de Cristo [...]» (2009: 157-158).

23.- Resma: hogei eskutada, hau da, bostehun paper-plegu. 
Bai, irakurri hala egiten da, horretan ez dago zalantzarik, baina geroi sortu zaigu dotrina honen euskarriak, paperak alegia, zer erakusten digun ez dakigulako, hau da, eskuizkribuak datatzeko darabilgun metodologia honetatik abiatuta, dotrinaren eskuizkribu hau aztertu gabe dugulako, eta jakin bai baitakigu paperaren gainean idatzita uzten diren hitzak ziurtatzeko edo egiaztatzeko baliabiderik garrantzitsuena dugula.

Hori dela eta, bi eginbehar nagusi ditugu: Oikiako Dotrina (1759) eskuizkribuaren egilea F. Antonio Agirre bera den egiaztatzea izango da lehena; data, 1759, ziurtatzea bigarrena, aurkeztu berri dugun dotrinaren ondotik ala aurretik idatzi zuen ziur esan ahal izateko.

\section{Oikiako Dotrina (1759)}

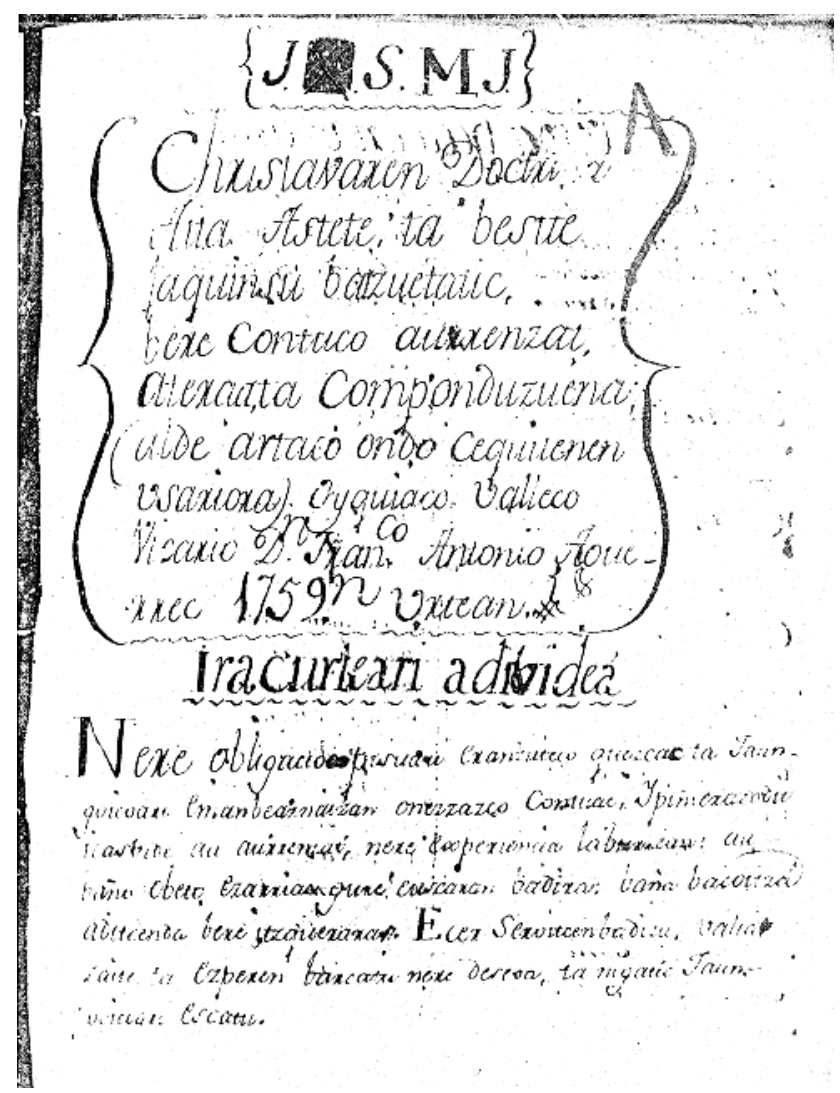

2.1. Oikiako Dotrina (1759)-ren egilea Frantzisko Antonio Agirre da?

Christavaren Doctrina honen lehenengo orrialdean Oyquiaco Valleco Vicario D.n Fran. 
co Antonio Aguerrec ateraa, ta compondua dela esaten da. Lehen aipatu dugun gisan, Aguerre ${ }^{24}$ irakurtzen da, eta ez Aguirre. Hutsegiteren bat dela garbi esan dezakegu, aurreko dotrinaren azterketaren emaitzek 1759ko maiatzetik Oikian erretore lanetan aritu zena Frantzisko Antonio Agirre izan zela garbi uzten baitute.

Deituraren kontua argiturik, eta aurrean eman ditugun berriak ikusita, aski datu ditugu egile bakar baten aurrean gaudela zalantzarik gabe esan ahal izateko. Alde batetik, letra mota bera da idazki guztietan ageri dena: Agirrek berak sinatutako agiri eta gutunetan, aurkeztu berri dugun dotrinan eta aurrean dugun honetan ere. Bestetik, dotrinaren eskuizkribu honen urtea egiaztatzeko egin dugun azterketak, Oikiako bikario izan zen garaikoa dela baieztatzen digu (1759-1805). Hortaz, Frantzisko Antonio Agirre Gabiria da dotrina honen egilea ere.

Dotrina hau kokatzen amaitzeko, azken urratsa ematea geratzen zaigu: Agirrek 1759. urtean idatzi zuen egiaztatzea.

\subsection{Oikiako Dotrina 1759an idatzia ote da?}

Gure susmoak eta zalantzak argitzeko papera aztertuko dugu, metodologia honen bidez testuan ematen den data paperak daramanarekin alderatuz, testuaren egiazkotasuna ziurta baitaiteke.

Ondoko ur marka hau aurkitu dugu dotrina idazteko erabili zituen paperetan:

24.- Urquijo liburutegian ere honela dago katalogatua: D. Francisco Antonio Aguerrec. Eskuizkribuaren sinadura zk. 4722 da. 


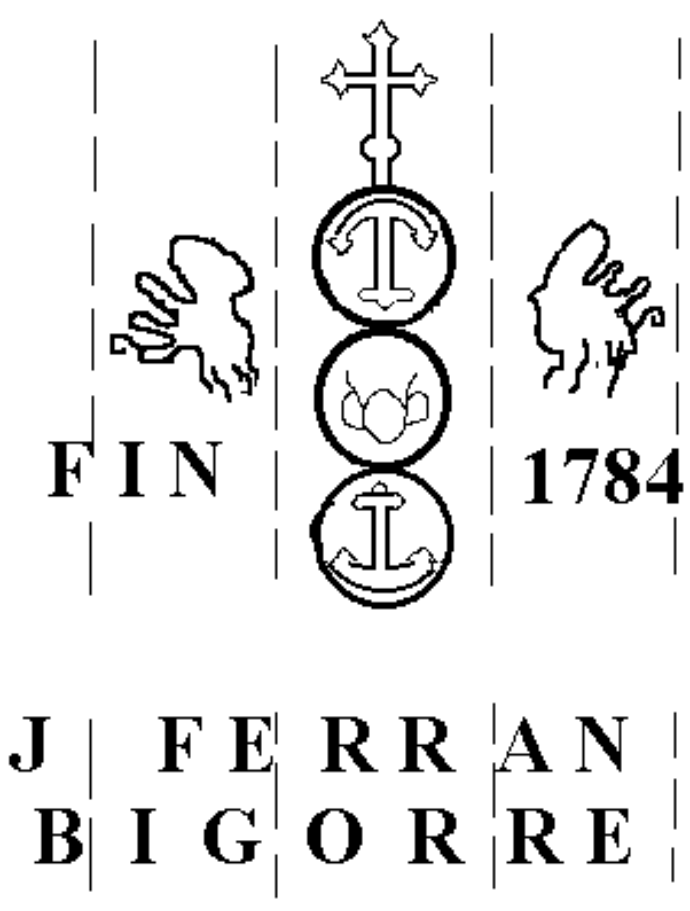

Hona, bada, ezustekoa:

1.- Agirrek dotrinaren eskuizkribu hau ez zuen 1784 baino lehenago idatzi

Ur markan ageri den datak papera 1784. urtean ekoitzi zela adierazten du. Agirrek ezin izan zuen, bada, dotrinaren eskuizkribua 1759an idatzi 1784. urtean ekoitzitako paperean. Beraz, esana utzi zuen eta uste genuena baino hogeita bost urte beranduagokoa da, gutxienez, eskuizkribu hau.

2.- Datu hauek kopia baten aurrean egon gaitezkeela aditzera ematen digute, Agirrek dotrinan ipini zuen data (1759) papera egin aurrekoa delako.

25.- Kontuan har pleguak tolestu eta ertzak moztu egiten zirela. Hori dela eta, paperaren kalitatea eta urtea orri hauetan aurkitzen dira: dotrinaren lehenengo orrian, 2., 4., 7., 9., 10., 12., 15., 16., 19., 21., 22., 24., 27., 29., 30. eta idatzi gabe dauden 33. eta 34. orrialdeetan ere.

26.- Papergilearen izena 6. orrian, 8., 14., 18., 20., 26. eta 32.ean ikusten da.

27.- Paperaren jatorria 3. orrian, 5., 11., 13., 17. eta 31.ean ageri da. 
3.- Papera aurreko dotrinan erabilitakoaren jatorri berekoa da, Bigorrakoa, alegia, baina ekoizlea aldatzen da: J FERRAN28.

4. Agirrek dotrinaren eskuizkribu hau Oikian idatzi zuen, berrogeita hamasei urte zituela.

5. Aurkeztu berri dugun dotrinaren ondoren idatzia da, gutxienez hamar urte beranduago.

Laburbilduz, eskuizkribu hau Frantzisko Antonio Agirrek gutxienez 1784. urtean idatzi zuen Oikian, bertako erretore zela azkeneko hogeita bost urteetan.

Bi dotrinak kokatu ondoren eta ondorioak azaldu aurretik, elkarren parean ipini ditzagun.

\section{Oikiako Dotrinak (1774-1784 [1759]). Antzak eta aldeak}

Papera egiterakoan paperaren gorputz barnean papergileak ezarri zuen ur marka baliabidetzat hartuta, Oikiako Dotrinak noiz idatzi ziren jakin dugu. Hemendik abiaturik bi dotrinak parean jarriko ditugu eta kanpoaldea jauzia eginez, oraingoan testuen irudiak jaso nahi ditugu, tamainaren, egituraren eta itxuraren aldetik, ur marken azterketaren emaitzekin duten lotura ikusi eta ondoko azterketetarako oinarriak finkatzeko asmoz ${ }^{29}$.

\subsection{Tamaina}

1774

174 orri idatziak
1784 [1759]

32 orri idatziak

Lehenengoa ia sei aldiz luzeagoa da. 1774koan Agirrek letra handiagoa egiten duen arren, dotrinaren zatien azalpenetan nabarmen luzatzen da: hirugarren zatiak, esaterako, bost orri hartzen ditu 1784ko dotrinan eta hirurogeita zortzi 1774koan.

28.- Ur marka berdintsua aurkitu berri dut (ikus 1 oharra), Donostiako S. Telmo museoan gordetzen den Jean de Paris pastoralaren eskuizkribuan. Pastoral hau datatu gabea da eta paperak daraman ur markak gai bera du (hiru O deiturikoa), aldaketa batzuekin: lehen biribilean gurutzea eta beste bietan bihotz bana. Ur markak 1783 urtea darama, hau da, Agirrek dotrina hau idazteko erabili zuen papera baino urtebete lehenago ekoitzia. Jatorria eta papergilea aldatzen dira, pastoral hori idazteko erabili zen papera Zuberoan ekoitzi baitzuen Pierre Bonase papergileak. Osatzen ari naizen ur marken bilduman, 1764an eta 1765ean datatutako eskuizkribuetan aurkitu dut P. Bonase (Bonasse) papergilea, Zuberoan. Ditudan beste zerrenda batzuetan, berriz, 1774tik aurrera ageri da beste papergile maisuen artean. Honek guztiak paperaren erabileraren garaia egiaztatzeko aukera eskaintzen digu. Hemendik eskerrak eman nahi dizkiot Iñaki Mozos Mujikari, aipatu dudan Jean de Paris pastoralaren eskuizkribu hori aztertzeko izan dudan aukera berari zor baitiot. Pastoral hau 1995ean aurkeztu zuen doktorego tesian aztertu zuen: Jean de Paris pastorala: eskuizkribuen azterketa eta iturriaren moldamoduak (orain helbide honetan da eskuragarri: http://edtb.euskomedia.org/5984/1/005984.pdf).

29.- Aurkeztu berri dugun dotrinaren (1774) edizioa prestatzen ari gara, eta orduan izango dugu barneko ezaugarriak alderatzeko aukera. 


\subsection{Egitura}

Asteteren dotrina itzultzen da bietan eta hurrenkera berean, ondoko taulan ikus daitekeen eran. 1774ko dotrinan agertzen ez diren zenbait zati gehitzen dira, ordea, 1784koan, azaldea edo declaracioa hasi aurrean. Haatik, azken honetan, beste dotrinaren zatiak laburrago azaltzen ditu, orri kopuruaren aldea ikusi besterik ez baitago.

Agirreren eskuz idatzitako bi testuon bertsio bakar hauek besterik ez ditugu ezagutzen. Ez dakigu, beraz, inprentara heldu balira testuek hartuko zuketen azken forma, ezta zein izan zen hauen hastapena ere, egoera honetara heldu aurretik. Hortaz, eskuizkribu autografoak eta lekukotasun bakarrekoak edo argitaragabeak direnez, ahalik eta zehatzen jasotzearen alde egin dugu, transkripzio diplomatikoa jarraituz. Erreprodukzio grafikoa ez ezik kronologikoa ere egin nahi dugu, testu genetikaren irizpideak aplikatuz, eta zuzenketak edo egilearen aldaera ezberdinak testuan bertan markatu ditugu (ugariak ez direnez, «testu garbia» eskaintzeko ez da bigarren baten beharrik). Horien kronologia adierazteko, berriz, jarraian aipatuko ditugun hainbat sinbolo edo ikur erabili dugu. Labur esanda, metodologia honek ahalbidetzen digu zuzenketa bat idazketa unean edo irakurketa baten ondoren egindakoa den bereiztea. Ikurren erabileran, halere, ez da batasunik, hau da, irakurketa bererako ikur ezberdinak aurki daitezke, nahiz eta hainbat errepikatzen diren (parentesiak, kako zuzenak, kako angeluarrak, marrak...), eta guk erabilienak egokitu ditugu testuotara. Hemen, transkribatutako zatietan ageri direnak besterik ez ditugu azalduko:

1. - ezabaketak: Salvet [Agirrek azken a ezabatu du];

2. $\quad<>$ eransketak: Gorpu<t>zaren [Gorpuzaren idatzi ondotik $t$ erantsi du: gorputzaren. Ezabaketaren ondoan bada, hitz edo letraren gainean egindako zuzenketa da: aguiz<tz>, $z$ ezabatu eta gainean $t z$ idatzi du: aguitz];

3. $<>$ lerro artean erantsia: Pia<e $>$ da $<$ de>tsua [lehen Piadatsua idazketatik, de erantsi du lerro artean, eta $a$ gainean $e$ berridatzi];

4. [ ] editorearen oharrak;

5. [...] transkribatu ez den testu-zatia. 


\begin{tabular}{|c|c|}
\hline 1774 & 1784 [1759] \\
\hline Iracurleari aurreraco videa & Iracurleari adib $<v>$ idea \\
\hline Bertso hauek ez daude & Avisoa pecatari gucienzat \\
\hline Sarrera -Gurutce Santuaren- & Sarrera -Gurutce Santuaren- \\
\hline Aita gurea & Aita Gurea \\
\hline Ave Maria & Ave Maria \\
\hline Salbe [Fedearen articuloac-en ondoren] & Salvea \\
\hline Credoa & Credoa \\
\hline Fedearen articuloac dirade amalau [7r] & Fedearen Articuloac Dira Amalau [3r] \\
\hline Jaungoicotasunari daozquionac dira oec & Jaungoicotasunari dagozquionac dira oec \\
\hline $\begin{array}{l}\text { Guigzontasun [sic] santuari dagozquionac } \\
\text { dirade oec }\end{array}$ & $\begin{array}{l}\text { Jesuchristoren guizontasunari dagozquionac dira } \\
\text { oec }\end{array}$ \\
\hline $\begin{array}{l}\text { Jaungoicoaren leguezco Mandamentuac } \\
\text { dirade Amar [8v] }\end{array}$ & $\begin{array}{l}\text { Jaungoicoaren Legueco Mandamentuac dira Amar } \\
{[3 \mathrm{v}]}\end{array}$ \\
\hline $\begin{array}{l}\text { Eliza Ama Santuaren Mandamentuac } \\
\text { dirade bost }\end{array}$ & Eliz Ama Santaren Mandamentuac dira bost \\
\hline $\begin{array}{l}\text { Obra Misericordiazcoac dirade amalau, } \\
\text { Zazpi espiritualac, ta zazpi corporalac }[9 \mathrm{v}]\end{array}$ & $\begin{array}{l}\text { Obra Misericordiazcoac dira Amalau. Zazpi } \\
\text { espiritualac edo animari dagozquionac, eta zazpi } \\
\text { gorporalac edo gorputzari dagozquionac [4r] }\end{array}$ \\
\hline Espiritualac dirade oec & Espiritualac dira oec \\
\hline Corporalac dirade oec & Zazpi gorporalac dira oec \\
\hline $\begin{array}{l}\text { Eliza Ama Santuaren Sacramentuac dirade } \\
\text { Zazpi [10r] }\end{array}$ & Eliz Ama Santaren Sacramentuac dira Zazpi [4r] \\
\hline Confesio generala & Confessio Generala \\
\hline Acto Contriciocoa & Actu Contriciocoa \\
\hline $\begin{array}{l}\text { Pecatu Capitalac edo pecatu beste gucien } \\
\text { buru, Yturri, ta sustraiac dira Zazpi [11v] }\end{array}$ & Pecatuen buru, iturri, edo Sustraiac dira Zazpi [5r] \\
\hline Zazpi vicio oien contra dira zazpi virtute. & Zazpi oen contra daude zazpi vertute \\
\hline $\begin{array}{l}\text { Igues eguin bear diotegun animaren etsaiac } \\
\text { iru dira. }\end{array}$ & Animaren etsaiac dira Iru \\
\hline Ez dakar & Espiritu Santuaren contraco pecatuac dira Sei \\
\hline Ez dakar & $\begin{array}{l}\text { Jaungoicoari benganza escatcendioen becatuac } \\
\text { dira Lau }\end{array}$ \\
\hline Ez dakar & Itsutcen gaituen barrungo burrucac dira Lau \\
\hline Ez dakar & Oracio oneraco gauzac dira lau \\
\hline
\end{tabular}




\begin{tabular}{|c|c|}
\hline $\begin{array}{l}\text { Virtute theologalac, edo } \\
\text { Jaungoicorequicoac [sic] dira iru }\end{array}$ & $\begin{array}{l}\text { Vertute theologal, edo Jaungoicoarequicoac dira } \\
<\mathrm{H}>\mathrm{iru}^{1}\end{array}$ \\
\hline Virtute cardinalac, edo principal dira lau & Vertute Cardinalac dira Lau \\
\hline Gorpuzaren Sentiduac dira bost & Gorputzaren Sentiduac dira bost \\
\hline $\begin{array}{l}\text { Animaren potenciae edo aalmenac dira iru } \\
{[12 \mathrm{v}]}\end{array}$ & Animaren aalmen edo potenciac dira Yru [6r] \\
\hline $\begin{array}{l}\text { Asquen gauzac Christabac beti gogoan } \\
\text { beardituanac dira lau. [13r] }\end{array}$ & Azquen gauzac dira lau \\
\hline Ez dakar & Gorputz gloriosoaren doteac dira Lau \\
\hline Ez dakar & Anima gloriatsuaren doteac dira Yru \\
\hline Ez dakar & $\begin{array}{l}\text { Christavaren vicitzaco dempora gucia hiru } \\
\text { puntutara dator }\end{array}$ \\
\hline Ez dakar & $\begin{array}{l}\text { Hiru puntu oec atribuitcenzaie hiru persona } \\
\text { Divinoai au da: }\end{array}$ \\
\hline Espiritu Santuaren doiac [sic] dirade Zazpi & Espiritu Santuaren Doaiac dira Zazpi \\
\hline Espiritu Santuaren frutuac dirade Amavi & Espiritu Santuaren Frutuac dira Amavi \\
\hline Bienaventurantzac, edo Zorionac dira Zorci & Bienaventuranzac, edo Zorionac dira Zortci \\
\hline Izare Santuco Oracioa [14r] & Izare edo Mandire Santuco Oracioa [7r] \\
\hline $\begin{array}{l}\text { Pecatu venialac barcaceco gautzac dira } \\
\text { bederaci }\end{array}$ & $\begin{array}{l}\text { Becatu arin edo venialac barcatcendira bederatci } \\
\text { gautzaren vitartez }\end{array}$ \\
\hline Ez dakar & $\begin{array}{l}\text { Meza enzutetic ateratcendiran provechu andietatic } \\
\text { bost }\end{array}$ \\
\hline Ez dakar & Confessio ona izateco beardiran bost gauzac \\
\hline Ez dakar & Fede, Esperantza, eta Caridadearen Actoac \\
\hline Ez dakar & Actu Esperantzacoa [8r] \\
\hline Ez dakar & Acto Caridadecoa \\
\hline Ez dakar & Actu Contriciocoaz valiatzaite modu onetan \\
\hline Ez dakar & $\begin{array}{l}\text { Ondo vicita gure pecatuen zorrac pagatceco edo } \\
\text { satisfacioraco eguinditzaquegun gauzac dira Yru }\end{array}$ \\
\hline $\begin{array}{l}\text { Salbacioraco jaquin beardiran gaucen } \\
\text { azaldea, edo esplicacioa. Lau gauza } \\
\text { dira bearrac, Christabac vetico zoriona } \\
\text { irabazteco, [...] oec beroc banaca azaldu, } \\
\text { edo esplicatuco dira emen galderaz, eta } \\
\text { eranzueraz [15r] }\end{array}$ & $\begin{array}{l}\text { Christau Doctrinaren azaldea edo declaratcioa, } \\
\text { galdetcen, eta eranzuten dala [9r] }\end{array}$ \\
\hline
\end{tabular}




\begin{tabular}{|c|c|}
\hline $\begin{array}{l}\text { Lau gauza dira bearrac, Christabac vetico } \\
\text { zoriona irabazteco }[\ldots]\end{array}$ & $\begin{array}{l}\text { Christau Doctrinaren zatiac. Lau gautza arrazoizco } \\
\text { ezagüerara eldutcen danean christavac jaquin } \\
\text { beardituanac }[10 \mathrm{v}]\end{array}$ \\
\hline $\begin{array}{l}\text { Lenengo jaquin vearra. Ezaguera } \\
\text { arrazoizcora eldutcen danean bada } \\
\text { Christavac lenen jaquin vearduana da, cer } \\
\text { sinistu bearduan. [15r/v-31r] }\end{array}$ & $\begin{array}{l}\text { Lau gautza oen azalde, edo declaratcioa cheatuago. } \\
\text { [Lehenengo zatia. } 11 \mathrm{r}-15 \mathrm{r} \text { ]. }\end{array}$ \\
\hline $\begin{array}{l}\text { Bigarren ezagueran sartu ezquero } \\
\text { Chistavaren [sic] jaquin bearraren azalde } \\
\text { edo explicacioa [31r-38r] }\end{array}$ & $\begin{array}{l}\text { Bigarren Cristavac jaquinbearduanaren azalde, edo } \\
\text { explicatcioa }[15 \mathrm{v}-17 \mathrm{r}]\end{array}$ \\
\hline $\begin{array}{l}\text { Ezaguera arrazoizcoan sartu ezquero } \\
\text { Christauac hirugarren Jaquin bearduanaren } \\
\text { explicacioa }\end{array}$ & $\begin{array}{l}\text { Hirugarren Cristavac jaquinbearduanaren } \\
\text { explicatcioa }\end{array}$ \\
\hline Elizaco bost mandamentuac & Elizaren Mandamentuac \\
\hline Obra misericordiazcoac & Obra Misericordiazcoac \\
\hline $\begin{array}{l}\text { Christauac laugarrena Jaquin bearduanaren } \\
\text { azalde, edo explicacioa [106r-148] }\end{array}$ & $\begin{array}{l}\text { Laugarren Cristavac jaquinbearduan gauzaren } \\
\text { azalde, edo explicacioa [20r-27r] }\end{array}$ \\
\hline $\begin{array}{l}\text { Becatu mortala ezagutceco bide edo } \\
\text { erreguelac [148]. Becatu Capitalac [158]. } \\
\text { [148r-162r] }\end{array}$ & Becatu Capitalac $[27 v-28 r]$ \\
\hline Animaren etsaiac [162r-163r] & Animaren etsaiac [28r] \\
\hline $\begin{array}{l}\text { Christauac beardituan vertuteac }[163 r- \\
\text { 166v] }\end{array}$ & Vertute Theologal, edo Jaungoicoarequicoac [28v] \\
\hline Azquen gauza [166v-169v] & Azquen gauza edo Novissimoac [28v-29r] \\
\hline Vertute Cardinalac [169v-170r] & Vertute Cardinalac edo Principalac [29r/v] \\
\hline Gorpu<t>zaren Sentiduac [170r/v] & Gorputzaren Sentiduac [29v-30r] \\
\hline Animaren Sentidu edo Potenciac [170v] & Animaren aalmen edo Potenciac [30r] \\
\hline Espiritu Santuaren Doaiac [171r] & Espiritu Santuaren doaiac [30r] \\
\hline Espiritu Santuaren frutuac [171r] & Espiritu Santuaren Frutuac [30v] \\
\hline $\begin{array}{l}\text { Zorionac, edo Bienabenturanzac [171v- } \\
174 \mathrm{r}]\end{array}$ & Bienaventuranza edo Zorionac [31r/v] \\
\hline $\begin{array}{l}\text { Ill, ta eguneroco Christabaren eguitecoac } \\
\text { conseju onac becela. Oeracoan }[174 \mathrm{r} / \mathrm{v}- \\
175 \mathrm{r} / \mathrm{v}]\end{array}$ & $\begin{array}{l}\text { Egunoroco Cristavaren eguitecoac consejuac } \\
\text { bezela. Ave Marietacoetan². Oeracoan [31v-32r/v] }\end{array}$ \\
\hline
\end{tabular}




\subsection{Tankera}

1784ko dotrinan alderdi hau ongi zaindu zuen Agirrek. Testua txukun idatzia ikusten da: ertzak xuxen errespetatzen ditu $(1,5 \mathrm{~cm})$, eta markatu dituela nabari da, bertan G[aldera] E[rantzuna] hizkiak jartzen dituelarik; dotrinaren zatiak ere garbi bereizten dira. 1774ko dotrina, aldiz, ez dago hain ongi taxutua eta letra handiagoa, zabarragoa ikusten da. Dotrinaren zatiak ez dira beti hain ongi bereizten: batzuetan, sarrera, galdera batean aurkitu behar da, zati batetik besterako jauzia 'Galderak' eta 'Erantzunak' jarraituz egiten baitu; beste zenbaitetan, marra batez bereizten ditu. Honela, oro har egituran den berdintasuna ez da itxurari dagokionean esan daitekeena, bien arteko aldea nabarmena baita, aukeratu dugun zatiak garbi erakusten duen gisan ${ }^{30}$ : 


\begin{tabular}{|c|c|}
\hline 1774 & 1784 [1759] \\
\hline $\begin{array}{l}\text { G. Cerda Caridadea? } \\
\text { E. Jaincoa amatcea gauza gucien gañean } \\
\text { bere ontasuna gatic, ta lagun proximoa } \\
\text { gueren buruac becela. [108r] } \\
\text { G. Batteatcen danac, cer esqueincen dio } \\
\text { Jaincoari? } \\
\text { E. [...]. } \\
\text { G. Nola batteatuco du? } \\
\text { E. [...]. } \\
\text { G. Batteatu gave Christaua da, edo } \\
\text { salbaditteque? } \\
\text { E. Ez Jauna, ez Christaua da, ta ez } \\
\text { salbatuco da. [110r] } \\
\text { G. Batteaturic dagoana becatu mortalic } \\
\text { eguin gave illcembada salbatua izango } \\
\text { da? } \\
\text { E. Bai Jauna ez dago onetan dudaric, } \\
\text { eztta ere dudavideric. Ta becatu mortal } \\
\text { asco eguin arren Christauac demboraz } \\
\text { eguiten badu penitencia eguiazcoa } \\
\text { ta irauten badu Jaincoaren gracian, } \\
\text { salbatuco da, Fede Santuco eguia da. } \\
\text { G. Noiz arttcendu Christauac } \\
\text { Confirmacioco Sacramentua Santua? } \\
\text { E. Obispo Jaunac Confirmatcenduanean. } \\
\text { [110r]. } \\
\text { [...] } \\
\text { G. Cer becatu? } \\
\text { E. Mortala Jauna. } \\
\text { G. Noiz arttcendu Christavac, } \\
\text { penitenciaco Sacramentu Santua? [110v] } \\
\text { E. Confesio ona eguitenduan gucian } \\
\text { Jauna. } \\
\text { [Etzana gurea da]. }\end{array}$ & 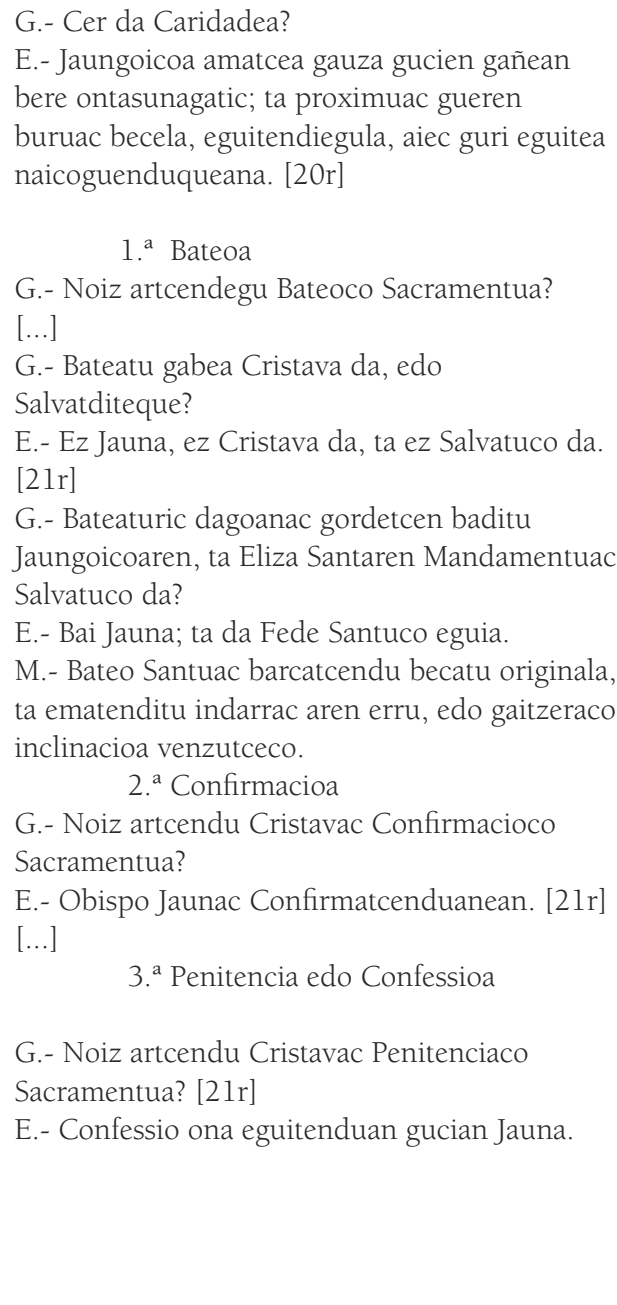 \\
\hline
\end{tabular}

Ondoko pasarteak ere honaino azaldu ditugun nahiz aipatu gabe utzitako ezaugarrien erakusgarri dira, zehatzago ikusteko aukera eskainiko baitugu prestatzen ari garen $1774 \mathrm{ko}$ dotrinaren edizioan: 


\begin{tabular}{|c|c|}
\hline 1774 & 1784 [1759] \\
\hline [1v] Iracurleari aurreraco videa. & [1r] Iracurleari adib<v>idea \\
\hline $\begin{array}{l}\text { Nere obligacio pisuari erantzuteco } \\
\text { quezcac, ta Jaungoicoari } \\
\text { emanbeardiodan onerazco contuac } \\
\text { ipinierazodit icasbide au aurrenzat, } \\
\text { aubaño obeto ipiniac gure euscaran } \\
\text { badira, baña bacoitza, aditcenda } \\
\text { bere izquerara. Ecer servitcenbadizu, } \\
\text { valiazaite, ta ezperen, barcatu nere } \\
\text { deseoa, ta nigatic Jaungoicoari } \\
\text { erregutu. }\end{array}$ & $\begin{array}{l}\text { Nere obligacio pisuari eranzuteco quezcac ta } \\
\text { Jaungoicoari emanbearnaizan onezzazco contuac, } \\
\text { Ipiñierazodit icasłb<v>ide au aurrenzat, nere } \\
\text { experiencia laburrean; aubaño obeto ezarriac } \\
\text { gure euscaran badira; baña bacoitza aditcenda } \\
\text { bere itzquerara. Ecer servitcenbadizu, valia } \\
\text { zaite ta ezperen barcatu nere deseoa, ta nigatic } \\
\text { Jaungoicoari escatu. [Etzana gurea] }\end{array}$ \\
\hline [14r] Izare Santuco Oracioa. & [7r] Izare edo Mandire Santuco Oracioa. \\
\hline $\begin{array}{l}\text { Gure Jaungoicoa, larga ciñisquiguna } \\
\text { zure pasioco siñaleac azpi izare } \\
\text { santu [14v] artan, nun vilducuten } \\
\text { zure gorpuz Santua gurutcetic } \\
\text { Josephec jachi zuanean. O Jaun } \\
\text { piadade gucicoa! iguzu arren zure } \\
\text { erioza, ta sepulturaren bidez eraman } \\
\text { gaizaten erresurrecioco gloriara, nun } \\
\text { viciceran eta erreinatcendezun, Aita } \\
\text { Jaungoicoarequin, Espiritu Santuaren } \\
\text { battasunean, irurac Jaungoico bat } \\
\text { tempora gucien temporetan } \\
\text { Amen. }\end{array}$ & $\begin{array}{l}\text { Jaun Jaungoicoa: Zure passioco Siñaleac } \\
\text { utcicinizquiguzuna Mandire Santu artan, ceñean } \\
\text { bildua izanzan zure gorputz guciz Santua Josef [sic] } \\
\text { guru }<\mathrm{t}>\text { cetic eratsizuanean. Eguin eguiguzu arren, } \\
\text { O Jaun guciz Pia }<\mathrm{e}>\mathrm{da}<\text { de }>\text { tsua! mesede, zure } \\
\text { eriotzata obiaren vitartez eramateaz Erresurreccioco } \\
\text { gloriara, nun viciceran, eta erreinatcendezun Aita } \\
\text { Jaungoicoarequin Espiritu Santuaren battasunean; } \\
\text { Iruroc Jaungoico bat dembora gucien demboran } \\
\text { Amen. }\end{array}$ \\
\hline
\end{tabular}

\section{Ondorioak}

D.n Francisco Antonio Aguirre, Oquiaco Vicarioac atera-a, ta compondua bere contura dauzcan Animen Oneraco dotrinaren eskuizkribua ezagutzera eman dugu, bertatik jasotako berriak egiaztatu eta ezkutukoak aztertu ditugu. Honela, idazki mota, nork, non eta noiz idatzi zenari buruzko datuak finkatuta utzi ditugu. Azterketa honen ondorioz, Oikiako dotrina (1759) berrikusi dugu eta eskuizkribuaren data ezaguna alboratuz, berria jakinarazi dugu. Bi eskuizkribuak parean jarri, eta hauen egilea eta urtea ezagutzeko nahiz egiaztatzeko erabili dugun metodologiaren baliagarritasuna, bada, agerian utzi dugu. Ikus ditzagun jarraian bildutako emaitzok:

4.1. Oikiako Dotrinen eskuizkribuak XVIII. mendeko bigarren erdikoak dira: gutxienez 1774. urtekoa eta 1784koa [1759]. 


\subsection{3,1774 eta 1784 urteetan Bigorran ekoitzi ziren paperetan idatziak dira.}

4.3. 1759 ko maiatzetik 1805 eko uztaila arte, zendu zen arte, Oikiako S. Bartolome parrokiako erretore izan zen Frantzisko Antonio Agirre Gabiria Segura eskoriatzarra dugu, bi dotrina hauen egilea (Marin 1728 - Oikia 1805). Eskuizkribuen paperen ur markek datu hauek egiaztatu dizkigute, biak 1759 urtearen ondoren idatziak baitira.

4.4. Urkixok Agirreren jaiotokiaz zuen susmo edo zalantza argitu eta orain arte ezjakinak ziren datuak ezagutzeko aukera eskaini du gure azterketak: Frantzisko Antonio Agirre 1728ko irailaren bian jaio zen, Gipuzkoako Eskoriatzako Marin auzoan. Oikiara joan aurretik Aia herrian egon zen, bikarioaren laguntzaile. Garai horretan bere sorlekuko parrokiaren ardura bere osabak zeraman, eta Oikiako parrokiako J. Zelaiaran erretorearen heriotza dela-eta, huts hori betetzera dator Agirre 1759ko maiatzean, hogeita hamaika urte zituela. Loiolako jesuitekin harreman estuak izan zituen, hauek baitzuten Oikiako misioen ardura, eta Kardaberazen lanak, behintzat, ederki asko ezagutzen zituen. Oikiako herriak ez zuen berrogeita sei urtez beste bikariorik ezagutuko, Agirrek bertan jarraitu baitzuen $\mathrm{M}^{\mathrm{a}}$ Santos Zavala iloba ondoan zuela, 1805ean zendu zen arte. Autore baten ibilbidea ezagutzea, edo kasu honetan Agirrerena, testuaren hizkuntza aztertzeko erabakigarria ez bada ere, bai, ordea, eskuizkribuaren egiazkotasuna baieztatzeko, ikusi dugun moduan.

4.5. Aurkeztu berri dugun dotrinaren eskuizkribua, Christau-ac Ezaguera arrazoizcora elduezquero Sinistu Jaquin, ta Eguin beardituan gaucen jaquin videa, gutxienez 1774. urtean idatzi zuen Agirrek. Oikian hamabost urte zeramatzan erretore lanetan eta berrogeita sei urte zituen.

4.6. Oikiako Dotrina (1759) izenez ezagutzen dugunaren eskuizkribua, gutxienez 1784koa dela agerian eta garbi utzi du gure azterketak. Aldi berean, eskuizkribuan irakurtzen den data, papera egin aurrekoa dela argitu dugu. 1759. urtean idatzia izan zela uste izan dugunaren aldetik, bada, mende laurdenaren aldea dugu dotrinaren eskuizkribu honetan. Ezagutzera eman dugun beste dotrina kontuan izanda, berriz, gutxienez hamar urte beranduagokoa da.

4.7. Datu hauek guztiek beste puntu jakingarri bat azpimarratuko ligukete: Oikiako Dotrina (1759) ez da jatorrizko eskuizkribua, kopia bat baizik.

Dotrinako sarrerari erreparatuz, aski adierazgarria da Agirrek «Ipiñierazodit icasvide au aurrenzat, nere experiencia laburrean;» esatea, hogeita bost urte Oikiako erretore zela (17591784), eta 1774ko dotrinan halakorik aipatzen ez duenean, hau da, hamar urte lehenago dotrinako zati berean ez ditu azpimarratu ditugun hitz horiek idazten, bi dotrinen alderaketari eskainitako atalean ere ikus ahal izan dugun eran (§ 3.3).

4.8. Azterketan zehar azaldutako datu eta ezaugarriek Oikiako Dotrina 1784 [1759] eta 1774koa molde berekoak ez direla erakusten dute, tamainari bakarrik begiratuta ere aldea nabarmena baita. 1784ko eskuizkribua, bada, Oikiara iritsi zen 1759. urteko azken sei hilabeteetan idatzitakoaren kopia izan liteke, edo 1774koa ere kontuan hartuz egindako 
berridazketa. Zein arrazoi edo asmo izan ote zuen Agirrek, hogeita bost urte lehenago idatzitako dotrinaren kopia egiten hasteko? Hala izan ezean, gainera, zer dela-eta atxiki zuen, bestela, 1759ko data? Hamar urte lehenago edo lehen hura idatzi zuenetik hamabost urtetara idatzitako hartan (1774koan), ez baitzuen urterik ipini. Ez da harritzeko ere biak ilunpean geratu izana, beste hainbat bezala, baina gogora dezagun hamazazpi urte igaro zirela (1767-1784) jesuitak erbesteratuak izan zirenetik, eta garai hartan, 60ko hamarkadan, Agirre Kardaberazen lanek zuten oihartzun eta zabalkundearen lekuko zela, bere idatzietan irakurri dugun moduan ( $\S$ 1.1); sarreran ere berea baino hobeto idatziak badirela aipatzen du. Hortaz, garai horretan argitaratzeko prestatu ote zuen, nahiz eta Ubillosek ere Christau doctrin berri-ecarlea orduan (1785ean) kaleratu? Gure usteak eta galderak ateak zabalik uzten ditu hemen, baina ez beste inon, paperean sartzen bagara ur markak maratila ixten baitu.

4.9. Eskuizkribuak urtea daramanean ere (1759), paperaren ur markak datu hori egiaztatzeko aukera eskaintzen du, Oikiako Dotrina ezaguna aztertzerakoan frogatu dugun bezala. Izan ditzakeen ondorioengatik data ongi ziurtatzea behar-beharrezkoa da, ur markak idazkiaren jatortasuna agerian uzten baitu.

4.10. Eskuizkribua datatu gabe egon arren, ur markak aztertuz idazkiaren garaia edo urtea jakitera irits gaitezkeela ikusi dugu berriro ere (Segurola 2002), aurkitu berri dugun Oikiako dotrinan erakutsi dugun gisan (1774). Zuhurtziaz jokatzea komeni bada ere, ur markak daraman data datu zehatza eta objektiboa da, idazkia garaian kokatu behar denean.

\section{Iturriak}

Aguirre, Francisco Antonio, Christau-ac Ezaguera arrazoizcora elduezquero Sinistu Jaquin, ta Eguin beardituan gaucen jaquin videa. Lazkaoko beneditarren monasterioko Euskal Liburutegian.

Aguirre, Francisco Antonio, Oikiako Dotrina (1759). Urquijo liburutegian, sinadura zb. 4722.

Lakarra, Joseba A., 1987, "Oikiako Dotrina (1759)", ASJU XXI: 2, 515-565.

Urquijo, Julio de, 1906, "Un catecismo vascongado de 1759. D. Francisco Antonio de Aguirre", Librairie Orientale et Américaine E. Guilmoto, Paris. Revue de Linguistique-n gehigarria.

Donostiako Elizbarrutiko Artxibo Historikoa.

Gipuzkoako Protokoloen Artxibo Historikoa.

Iruñeko Elizbarrutiko Artxibo Historikoa.

Lazkaoko beneditarren Euskal Liburutegia.

Loiolako Jesulagunen Artxibo Historikoa. 


\section{Bibliografia}

Actas del V Congreso Nacional de Historia del papel en España, 2003, Sarrià de Ter (Girona).

Actas del VI Congreso Nacional de Historia del papel en España, 2005, Buñol (Valencia).

Agati, M ${ }^{a}$ L., 2003, Il Libro Manoscritto. Introduzione alla Codicologia, Roma: L'Erma di Bretschneider.

Alibaux, H., 1926, Les premières papeteries françaises, Paris.

Alvarado Planas, J., 2009, "Las marcas de agua o filigranas de los maestros papeleros" in Alvarado Planas, J., Heráldica, simbolismo y usos tradicionales de las corporacioes de oficios: las marcas de canteros, Madrid: ed. Hidalguía, 155-171.

Arana Martija, J.A., 1994, "Euskal Herriko inprentaren historia", Uztaro 12, 1994, 37-53.

Arcocha-Scarcia, A. et al. (ed.), 2010, En el taller del escritor : génesis textual y edición de textos, Bilbo: UPV-EHU.

Asenjo Martínez, J.L., 1961, El papel y su fabricación, Madril: INLE.

Bofarull y Sans, Fr. de, 1901, "La heráldica en las filigranas del papel", Memorias de la Real Academia de Buenas Letras VII, 1901, 485-556, Barcelona.

, 1910, Los animales en las marcas del papel, Villanueva y Geltrú: Oliva.

Bouyer, Ch., 1994, L'histoire du papier, Belgique: Brepols.

Briquet, Ch.-M., 1923², Les filigranes. Dictionnaire historique des marques du papier dès leur apparition vers 1282 jusqu'en 1600 (4 libk.), Leipzig: Karl W. Hiersemann.

Burón Castro, T., 1995, "Estado actual del estudio de las filigranas en España. Filigranas en Castilla y León”, Invetigación y técnica del papel V (32-124), 1995, 317-333.

Cabanes, M.D., 1995, "Estado actual del estudio de las filigranas en España. Filigranas en Aragón", Investigación y técnica del papel V (32-124), 1995, 312-316.

Cabanes, M.D.; Cabanes, M.L., 1974, "Las filigranas del Archivo Municipal de Estella", Príncipe de Viana 35 (136-137), 1974, 483-505.

Casamassima, E., 1953, "Note sul metodo della descrizione del codici", Rassegna degli Archivi di Stato 23, 1953, 181-205.

Churchill, W.A., 1967, Watermarks in paper in Holland, England, France... in the XVII and XVIII centuries and their interconnection, Amsterdam: Menno Hertzberger \& Co.

Dain, A., 1949, Les manuscrits, Paris: Les Belles Lettres.

Frutiger, A., 1978, Der Mensch und seine Zeichen, Zurich. [C. Sánchez Rodrigo-ren itzulp.:] Signos, simbolos, marcas, señales, Barcelona: G. Gili, 1981.

Garcia Serrano, R., 1974, "El molino de papel del Hospital General de Pamplona", Cuadernos de Etnología y Etnografía de Navarra 16, 1974, 7-21.

Gaudriault, R., 1995, Filigranes et autres caractéristiques des papiers fabriqués en France aux XVIIe et XVIIIe siècles, Paris: CNRS Éditions et J. Telford.

Gayoso Carreira, G., 1966, "Dos españoles, los gallegos Antonio y Miguel, introdujeron la fabricación del papel en Germania y Basilea”, Investigación y técnica del papel 9 (jul.), 1966, 589-610.

, 1973, "Antigua nomenclatura papelera española", Investigación y técnica del papel 35, 1973, 29-53.

1994, Historia del Papel en España (3 libk.), Lugo: Servicio de Publicaciones de la Diputación Provincial.

Gilissen, L., 1977, Prolégomènes à la Codicologie. Recherches sur la construction des cahiers et la mise en page des manuscrits médiévaux, Gand: éditions scientifiques story-scientia. 
Insausti, S. de, 1966, "Nemesio Uranga: Industrial papelero en Tolosa antes que 'Hermano separado"', BAP XXII, 1966, 173-190.

Irigoin, J., 1980, "La datacion per les fililgranes du papier", Codicologica 5, 1980, 9-36.

Labayen, A.M., 1947, Escenas Papeleras, Zarauz: Icharopena.

1967, “¿Cuál fue la primera fábrica de papel en Guipúzcoa?”, BAP XXIII: 1, 1967, 101-104.

La Lande, Mr. de, 1778, Arte de hacer el papel según se practica en Francia y Holanda, en la China y en el Japón, M.G. Suárez y Núñez-en itzulp., Madrid: Clan, 1995.

Lemaire, J., 1989, Introduction à la codicologie, Louvain-la-Neuve: Institut d'études médiévales.

Marcas de agua en papeles del siglo XVIII (Marcas de agua en los libros de cuentas de Fabrica de las Iglesias de San Nicolas y de Santa Maria de Alicante), 1977, Seleccion de Vicente Martinez Morella, Publicaciones de la Obra Social y Cultural de la Caja de Ahorros Povincial de Alicante.

Masai, F., 1950, "Paléographie et codicologie", Scriptorium 4, 1950, 279-293.

Nicolaï, A., 1935, Histoire des moulins à papier du Sud-ouest de la France (1300-1800), I-II , Burdeos: G. Delmas.

Ostos, P.; Pardo, Ma L; Rodriguez, Elena E, 1997, Vocabulario de Codicología, Madrid, Arco/ Libros.

Panyella, L., 1976, La Filigrana de papel, Burriana: Papelera del Mijares, S.A., Papelera del Cid, S.A.

Petrucci, A., 2001², La descrizione del manoscritto. Storia, poblemi, modelli, Carocci.

Ruiz García, E., 1988, Manual de codicología, Madrid: Fundación Germán Sánchez Ruipérez. 2002, Introducción a la Codicología, Madrid: Fundación Germán Sánchez Ruipérez.

Sánchez Mariana, M., 1995, Introducción al libro manuscrito, Madrid: Arco/Libros.

Sánchez Real, J., 1974, "Criterios a seguir en la recogida de filigranas", Ligarzas 6, 1974, 361371.

Segurola, K., 2001, "Paperaren ur markak", ASJU 35: 1, 2001, 215-240. ,2002, "Jeanne d'Arc pastoralaren eskuizkribua: le plus ancien connu?", Lapurdum VII, 2002, 313-326. 2004, "XVIII. mendeko autore ezezagun bat", Lapurdum IX, 2004, 243-282. 2010, "Estudio de varios manuscritos anónimos del s. XVIII" in Arcocha-Scarcia, A. et al. (ed.), En el taller del escritor : génesis textual y edición de textos, Bilbo: UPV-EHU, (Filología y Lingüística 17), 187-207.

Valls i Subirà, O., 1965, "La filigrana del peregrino", Investigación y técnica del papel 6, 1965, 631-643.

1970, El papel y sus filigranas en Cataluñ / Paper and watermarks in Catalonia (2 libk.), Amsterdam: Paper Publications Society (Labarre Foundation).

1978, 1980, 1982, La historia del papel en España (3 libk.), Madrid: Empresa Nacional de Celulosas, S.A.

Vezin, J., 1978, "La réalisation matérielle des manuscrits latins pendant le haut Moyen Âge", Codicologica 2, 1978, 15-51. 
